\title{
Extracellular Chaperones as Novel Biomarkers of Overall Cancer Progression and Efficacy of Anticancer Therapy
}

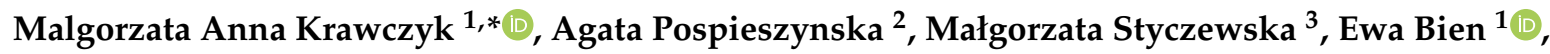 \\ Sambor Sawicki ${ }^{2}$, Antonella Marino Gammazza ${ }^{4} \mathbb{D}$, Alberto Fucarino ${ }^{4} \mathbb{D}^{\mathbb{D}}$ and \\ Magdalena Gorska-Ponikowska ${ }^{5, *(\mathbb{D})}$ \\ 1 Department of Pediatrics, Hematology and Oncology, Medical University of Gdansk, 7 Debinki Street, \\ 80-211 Gdansk, Poland; ewa.bien@gumed.edu.pl \\ 2 Department of Gynecology, Oncologic Gynecology and Gynecologic Endocrinology, Medical University of \\ Gdansk, 80-211 Gdansk, Poland; agata.pakulniewicz@gmail.com (A.P.); sambor.sawicki@gumed.edu.pl (S.S.) \\ 3 The English Division Pediatric Oncology Scientific Circle, Medical University of Gdansk, \\ 80-211 Gdansk, Poland; mstyczewska@gumed.edu.pl \\ 4 Department of Biomedicine, Neurosciences and Advanced Diagnostics (BiND), University of Palermo, \\ 90127 Palermo, Italy; antonella.marino@hotmail.it (A.M.G.); fucaro1984@gmail.com (A.F.) \\ 5 Department of Medical Chemistry, Medical University of Gdansk, 17 Debinki Street, 80-211 Gdansk, Poland \\ * Correspondence: mkrawczyk@gumed.edu.pl (M.A.K.); m.gorska@gumed.edu.pl (M.G.-P.); \\ Tel.: +48-58-349-28-80 (M.A.K.); +48-58-349-14-50 (M.G.-P.); \\ Fax: +48-58-349-29-50 (M.A.K.); +48-58-349-14-56 (M.G.-P.)
}

Received: 29 June 2020; Accepted: 27 August 2020; Published: 30 August 2020 updates

\begin{abstract}
Exosomal heat shock proteins (Hsps) are involved in intercellular communication both in physiological and pathological conditions. They play a role in key processes of carcinogenesis including immune system regulation, cell differentiation, vascular homeostasis and metastasis formation. Thus, exosomal Hsps are emerging biomarkers of malignancies and possible therapeutic targets. Adolescents and young adults (AYAs) are patients aged 15-39 years. This age group, placed between pediatric and adult oncology, pose a particular challenge for cancer management. New biomarkers of cancer growth and progression as well as prognostic factors are desperately needed in AYAs. In this review, we attempted to summarize the current knowledge on the role of exosomal Hsps in selected solid tumors characteristic for the AYA population and/or associated with poor prognosis in this age group. These included malignant melanoma, brain tumors, and breast, colorectal, thyroid, hepatocellular, lung and gynecological tract carcinomas. The studies on exosomal Hsps in these tumors are limited; however; some have provided promising results. Although further research is needed, there is potential for future clinical applications of exosomal Hsps in AYA cancers, both as novel biomarkers of disease presence, progression or relapse, or as therapeutic targets or tools for drug delivery.
\end{abstract}

Keywords: exosomes; heat shock proteins; cancer; adolescents and young adults; AYA

\section{Introduction}

\subsection{Pathophysiological Role of Heat Shock Proteins}

Heat shock proteins (Hsps) are ubiquitously expressed housekeeping chaperones responsible for maintaining homeostasis. Hsps associate in protein folding and protection of the proteome against misfolding and aggregation dangers under physiological conditions. Hsps also promote survival of 
cells exposed to hypoxia, infection, increased temperature, and chemical and physical factors [1-3]. Consequently, Hsps have been found to be upregulated in cells subjected to various proteotoxic stressors as an adaptive response in order to promote cell survival.

Hsps overexpression seems to be well correlated with cancer development and resistance to chemotherapy, making Hsps promising tumor biomarkers [4,5]. Indeed, Hsps molecular chaperone levels have been found to be elevated in many cancers, and their overexpression has been associated with poor overall survival and poor response to therapy in specific cancer types [6-10].

The three major families of Hsps whose expressions and activities are abnormally enhanced in cancer are the Hsp60, the Hsp70, and the Hsp90 families [11]. Small Hsps and Hsp40 are also upregulated in malignancies. The small Hsps family includes molecules with a molecular weight of 12-43 kDa, e.g., Hsp20, Hsp22, and Hsp27 [12].

The most abundant eukaryotic Hsp protein is Hsp90, which is a ubiquitously expressed protein with a molecular weight of $90 \mathrm{kDa}$. Its expression level is estimated to be $1-2 \%$ of total proteins under physiological conditions [13-15]. Two cytoplasmic isoforms, Hsp90 alpha (Hsp90AA1, Hsp90a, HspC1) and Hsp90 beta (Hsp90AB1, Hsp90b, HspC3), and the ER homolog, glucose-regulated protein 94 (GRP94, Hsp90B1), have been distinguished [14,15]. Hsp90 alpha and Hsp90 beta are both constitutively expressed isoforms. However, Hsp90 alpha is believed to be more inducible in response to great variety of stimuli $[14,16]$. An increased level of Hsp90 alpha seems to be principally associated with tumor progression and sustained cancer cell proliferation. Hsp90 beta is primarily responsible for development of drug resistance and long-term cellular adaptations [17]. Hsp90 is expressed at 2-10 fold higher levels in cancer cells compared to normal cells and is suggested to be one of the key factors implicated in promotion of cancer cell survival and metastases [18].

Hsp70 is a chaperone that, together with Hsp90, constitutes part of the major chaperone machinery. Several Hsp70 family members have been distinguished in humans, including stress-inducible Hsp70 (Hsp72, HspA1) and constitutively expressed HSC70 (Hsp73, HspA8) [19,20]. Each Hsp70, similar to Hsp90 proteins, is an ATP-dependent chaperone. Hsp70 and Hsp90 proteins are believed to be antiapoptotic heat shock proteins. However, the mechanisms of their action still remain controversial. Hsp70 family members may be involved in passing the newly synthesized unfolded proteins to Hsp60 proteins under physiological conditions. Hsp70s are engaged in protein translocation, facilitating degradation, and control of the activity of a great number of proteins, mainly transcription factors [20-22].

Hsp60 is a highly conservative chaperonin that is primarily found in mitochondria. Mitochondrial Hsp60 functions as an oligomer of fourteen $60 \mathrm{kDa}$ subunits. It cooperates with the heptameric $10 \mathrm{kDa}$ Hsp10 complex, which forms a lid, closing the Hsp60 tetradecamer opening [23,24]. This Hsp60/Hsp10 complex is responsible for mitochondrial protein homeostasis, including active folding of unfolded proteins and ATP-dependent proteolysis of denatured or misfolded proteins $[25,26]$. It has been shown that mitochondrial production of Hsp60 is significantly increased under stress conditions. However, small amounts of Hsp60 protein have also been detected in the cytosol [26]. Cytosolic Hsp60 can be detected as a monomer, but only oligomers can be active [24]. The role of cytosolic Hsp60 is not clear; however, many studies have indicated its involvement in either pro- or anti-apoptotic processes [27-30]. Extracellular release of Hsp60 either through secretion or as a result of cell necrosis has been reported as well [31,32].

One of the best known small Hsps is Hsp27 with a molecular weight of $27 \mathrm{kDa}$. It is a multi-functional and ATP-independent protein that can be found in the nucleus and cytoplasm in nearly all tissues. However, the function of $\mathrm{Hsp} 27$ as a protein chaperone has not been extensively examined compared to other Hsps [33]. HSP27 is composed of the WDPF domain, $\alpha$-crystallin domain, PSRLFDQXFGEXLL sequence, and C-terminus. The $\alpha$-crystallin domain with an active structure is associated with oligomerization [34,35]. Hsp27 is able to form multimeric aggregates (alone or with other small Hsps, e.g., Hsp20) and thus stabilize different proteins by facilitating the refolding of denatured proteins into active forms [36] and protect cells from death [37]. Hsp27 is also involved 
in regulation of apoptosis mediated by increasing antioxidant defense of cells and interactions with STAT3, cytochrome c-1 and pro-caspase 3 [38-40]. It was shown that Hsp27 is overexpressed in various physiological (cell development, differentiation, aging) and pathological conditions, including cancers. High expression of Hsp27 is associated with increased tumorigenic potential of neoplastic cells, leading to a poor prognosis in many cancer types [41-49]. Moreover, upregulated Hsp27 is associated with resistance to cytostatics in neoplastic cells [50-55] and inhibits the apoptosis caused by radiation [56-58]. Hsp27, as a significant molecule involved in apoptosis, seems to be an interesting target in cancer therapy.

The Hsp40 family is a large group of a co-chaperones. Hsp40 has been found in the cytosol, nucleus, mitochondria, ribosomes, endosome and endoplasmic reticulum. It is involved in protein translation, folding, unfolding, translocation, and degradation. There are three subclasses of Hsp40: A, B and C. Subclasses A and B work independently of ATP and reduce stress in cells by inhibition of protein aggregation. Moreover, subclass A of Hsp40 can bind proteins and prevent their aggregation without Hsp70. Subclass B binds protein independently of Hsp70; however, it must be connected with Hsp70 to prevent the aggregation of proteins [59]. Subclass C of Hsp40 is strictly dependent on Hsp70 [59,60]. The complex of Hsp40-Hsp70 together with Hsp90 takes part in upregulation of the Akt pathway, associated with upregulation of cellular survival. However, the role of the Hsp40 family in cancers has not been extensively investigated and current data are rather controversial. Some authors underlined that Hsp40 co-chaperones are involved in tumor growth [61]. Furthermore, studies on different cell lines suggest that high expression of Hsp40 is correlated with invasion and progression of cancer cells [62-64]. From another point of view, the inhibition of neoplastic cell proliferation induced by overexpressed Hsp40 has been reported [65]. Therefore, further studies are important to understand the role of Hsp40 in the biology of malignancies.

\subsection{The Role of Heat-Shock Proteins in Tumor-Associated Hypoxia and in Metastasis Formation}

Hypoxia is a characteristic feature of solid tumors. It is caused by insufficient oxygen supply, not meeting the demands of rapidly proliferating cells. Both the production and extracellular release of Hsps are strongly dependent on the hypoxic tumor microenvironment [66-68]. Various Hsps have been found to be overexpressed upon hypoxic conditions, including Hsp27 [69], Hsp70 [70], and Hsp90 [71,72]. The main hypoxia-modulated proteins responsible for downstream induction of Hsps are heat shock factor 1 (HSF1) and hypoxia-inducible factor 1 (HIF1) [72,73].

On the other hand, Hsps are also involved in HIF1 regulation. HIF1, acting via downstream factors like vascular endothelial growth factor (VEGF) and nitric oxide synthase (NOS), induces neo-angiogenesis [74]. Both Hsp70 and Hsp90 were found to stabilize HIF1 subunit $\alpha$ (HIF1 $\alpha$ ), VEGF and NOS $[75,76]$. One of the reported mechanisms of HIF1 $\alpha$ stabilization is direct binding of Hsp70 to its oxygen-dependent degradation domain [77]. In glioma, the modulation of HIF1 by Hsp90 was found to be involved in maintaining the tumor stem cell phenotype. The HIF1 stabilization led to increased expression of stem cell markers, including CD133 and nestin. Consequently, inhibition of Hsp90 impaired the HIF1 expression and resulted in the loss of stemness by glioma cells [78]. Thus, the Hsps undergo complex interactions with other hypoxia-induced factors, playing a significant role in tumor progression via promoting neo-angiogenesis and maintaining the stemness of cancer cells.

The hypoxia-induced Hsps are also known to promote cell motility both in physiological conditions and in cancer. It was reported that HIF1 induced the extracellular secretion of Hsp90 $\alpha$, which stimulated the migration of fibroblasts [72,79]. The secreted Hsp90 $\alpha$ binds to the specific receptors on the membranes of target dermal and epidermal cells [80]. Hsps may also interact with extracellular matrix (ECM) proteins. Hsp90 was found to alter the fibronectin expression in prostate cancer and mediate the matrix metalloproteinase 2 (MMP2) activity in fibrosarcoma [81,82]. Hsp72 expressed on exosomes released from tumor cells may also activate myeloid-derived suppressor cells (MDSCs), contributing to the immune evasion of the tumor [83]. These mechanisms are involved in tumor invasiveness and metastasis formation. 


\subsection{Exosomal Heat Shock Proteins as Biomarkers of Cancer Progression and Efficacy of Anticancer Therapy}

Exosomes are nanometer-sized bioactive vesicles secreted by a diverse range of cells and present in body fluids, such as: blood, urine, cerebrospinal fluid, breast milk and saliva, as well as bronchoalveolar lavage, ascitic and amniotic fluids [84].

Exosomes under an electron microscope have a "cupped" or "saucer-like" morphology $[85,86]$. There are various validated methods for exosome extraction. In most studies, exosomes were isolated from various cell lines [87-98], autologous tumor cells [99], blood [95,100,101], urine [95], or ascites samples [92,102]. Supernatants were separated by serial centrifugation at low speed to eliminate cellular debris and filtration [87-90,95,99-101]. Then, exosomes were ultracentrifuged and washed in phosphate-buffered saline solution. The assessment of the exosomal fraction was performed by electron microscopy $[87,89,93,97,99,100,102]$, Western blot analysis [87-89,96,98-103], Bradford assay [89,91], bicinchoninic acid (BCA) assay [92,94], NanoSight LM10 tracking system [95,97], or acetylcholinesterase assay [100].

The molecular content of exosomes reflects the specialized functions of the original cells. However, the fate of exosomes remains enigmatic. They are able to bind target cells and/or exchange molecules, thus modulating the activity of other cells. Many families of proteins are expressed on the surface of exosomes, such as targeting/adhesion molecules, membrane and cytoskeleton molecules, Hsps and signal transduction proteins [104-106].

It has been demonstrated that various cancerous cells release exosomes containing Hsps-either by passive release, e.g., from damaged, stressed, or dead cells, or active release, including secretion of Hsp-containing exosomes [91,107-109]. It has been hypothesized that pathological conditions, such as fever and acidosis, would increase the leakiness of exosomes and release of Hsps e.g., Hsp60 [110]. As reported by the Knowlton group, different stimuli will result in different proteins being released in exosomes from the same cell type. They showed that exosomes may form in the multivesicular body, which either traffics to the lysosome or fuses with the plasma membrane, emptying its contents of exosomes into the extracellular space [110]. However, the regulation of the release of exosomal Hsps, remains to be elucidated.

These exosomal Hsps play many important roles in cancer, including: immune system regulation [91,111,112], cell differentiation [113,114], vascular homeostasis [109], angiogenesis, epithelial-mesenchymal transition (EMT), cell migration, invasion and metastasis formation [76,88,115-119]. Moreover, exosomes also contain lipids, and various types of RNA and DNA, which may be used for malignant growth and dissemination [120-126].

Several studies have reported that elevated levels of Hsps can protect malignant cells against therapy-induced apoptosis [3,127]. It has been suggested that exosomes released by tumor cells are essential factors involved in the resistance-associated secretory phenotype (RASP) of cells. Molecular co-transfer of Hsps with oncogenic factors to recipient cells can promote cancer progression and resistance against stresses such as hypoxia, radiation, drugs, and immune systems. In addition, the RASP of tumor cells can eject anticancer drugs, targeted therapeutics, and immune checkpoint inhibitors with oncosomes [128].

Recent studies have also confirmed that Hsps localized on the surface of exosomes, secreted by normal and tumor cells, are the key players in the intercellular cross-talk during the course of cancer. It has been reported that microvesicles expressing Hsp70 on their surface activate immune system cells, including natural killer (NK) cells [91,129] and macrophages [130]. Increased levels of exosomal Hsps, including Hsp90, Hsp70, and Hsp60 have been associated with poor outcome in several malignancies [3].

Therefore, it seems that exosomal Hsps offer significant opportunities for clinical applications, as potential novel biomarkers of the diagnoses or prognoses of different diseases, or for therapeutic applications and drug delivery. 


\subsection{Adolescents and Young Adults (AYA)}

In this review we focus particularly on the role of exosomal Hsps as biomarkers in cancers developing in adolescents and young adults (AYA). AYA comprises patients aged 15-39 years. The most common cancers in AYA include: carcinomas (of the thyroid, breast, cervix, ovary, colon and liver), melanoma, brain and other central nervous system (CNS) tumors, germ cell tumors, sarcomas and lymphomas [131-133]. The distribution of particular tumors differs in the age subgroups of 15-19, 20-29 and 30-39 year-old patients [133].

The AYA age group, placed between pediatric and adult oncology, poses a particular challenge for diagnostics and therapy [134]. Consequently, the results of oncological treatment in AYA have been, for decades, worse than in other age groups with the same cancers. In addition, the progress in management of cancers occurring in AYA, measured as the mortality rate reduction, has been much smaller than in other age groups for many years [135]. Therefore, new biomarkers of cancer growth and progression as well as prognostic factors to predict response to therapy and final outcome are desperately needed in AYA.

\section{Materials and Methods}

A MEDLINE/PubMed database search was performed to identify studies reporting the role of exosomal Hsps (small Hsps, Hsp40, Hsp60, Hsp70 and Hsp90 families) in selected AYA cancers. The following key words were searched together with their appropriate synonyms, abbreviations and MeSH terms: "heat shock proteins" and "chaperones" combined with "exosomes" and "extracellular vesicles". All terms were searched in selected AYA neoplasms: carcinomas of the thyroid, breast, cervix, endometrium, ovary, colon, liver, lung, melanoma and malignant CNS tumors. The search was limited to manuscripts published in English from I' 1990 to V' 2020. The reference lists in all publications were also searched for additional studies. Articles in languages other than English, studies analyzing exosomal Hsps in benign diseases and malignancies not included in this review, studies analyzing the exosome-detection methodology only, studies not defining the precise location of analyzed Hsps and reviews were excluded from analysis. Summary of the methodology of the exosomes' determination and the clinical values of reviewed studies is presented in Table 1 and in Figure 1.

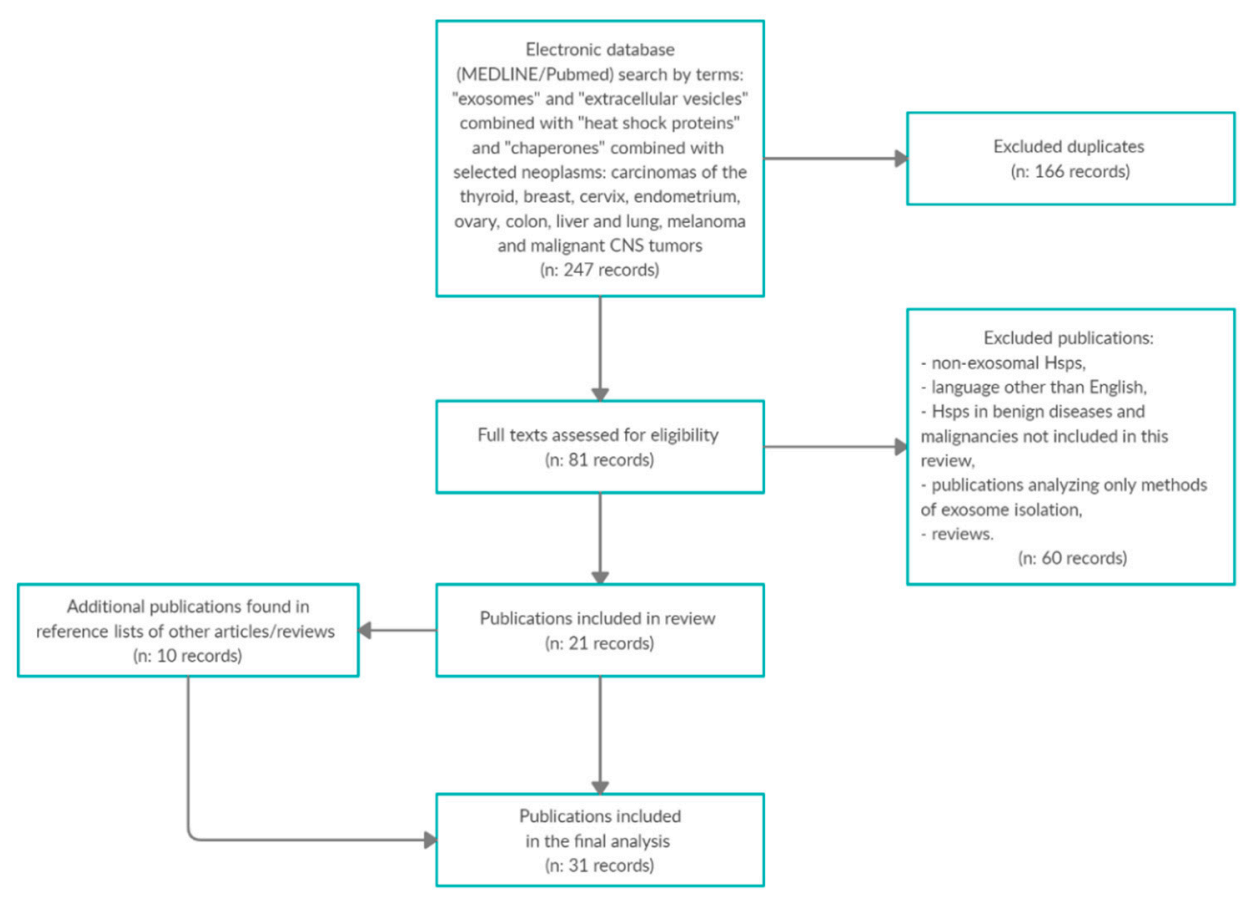

Figure 1. Summary of the methodology of the exosomes' determination and the clinical values of reviewed studies. 
Table 1. Summary of the methodology of the exosomes determination and their clinical values.

\begin{tabular}{|c|c|c|c|c|c|}
\hline Cancer Type & Analyzed Material & Exosomal Hsps & Clinical Values & Location & References \\
\hline \multicolumn{6}{|l|}{ CNS } \\
\hline $\begin{array}{l}\text { glioma, glioblastoma } \\
\text { multiforme, murine } \\
\text { anaplastic astrocytoma }\end{array}$ & cell lines & $\begin{array}{l}\text { Hsp27, Hsp60, Hsp70, } \\
\text { Hsp90, others }\end{array}$ & - & not mentioned & {$[87,136]$} \\
\hline glioblastoma multiforme & cell line & 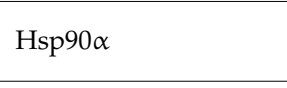 & $\begin{array}{l}\text { increase in tumor cells motility by activating plasmin; } \\
\text { tumor progression and metastasis formation }\end{array}$ & not mentioned & [88] \\
\hline glioblastoma multiforme & human tumor tissue & Hsp70 & $\begin{array}{l}\text { antitumor immunostimulation (induction of } \\
\text { glioma-specific cytotoxic CD8+ T-cells response) }\end{array}$ & not mentioned & [99] \\
\hline \multicolumn{6}{|l|}{ Melanoma } \\
\hline- & cell lines, human plasma & Hsp70, Hsp90 & possible use as a diagnostic marker & not mentioned & {$[89,137,138]$} \\
\hline- & human ascites aspirate & Hsp70, Hsp80 & - & not mentioned & {$[102]$} \\
\hline- & mice tumor tissue & Hsp70 & $\begin{array}{l}\text { inhibition of melanoma progression and } \\
\text { dissemination via activation of NK cells }\end{array}$ & exosomal surface & [90] \\
\hline- & cell line & Hsp70 & $\begin{array}{l}\text { inhibition of antitumor immune response via } \\
\text { activation of the myeloid-derived suppressor cells }\end{array}$ & exosomal surface & [95] \\
\hline \multicolumn{6}{|l|}{ Colorectal carcinoma } \\
\hline- & human blood & Hsp60 & possible biomarker of recurrence & exosomal surface & {$[100]$} \\
\hline- & $\begin{array}{l}\text { cell lines, human ascites } \\
\text { aspirate }\end{array}$ & Hsp70 & $\begin{array}{l}\text { induction of anti-tumor immune response via } \\
\text { activation of NK cells and Hsp70-dependent IL-6 } \\
\text { secretion from dendritic cells }\end{array}$ & $\begin{array}{l}\text { exosomal surface } \\
{[91,95] / \text { not mentioned }} \\
{[92]}\end{array}$ & {$[91,92,95]$} \\
\hline- & cell lines & Hsp70 & $\begin{array}{l}\text { release of immunogenic exosomes containing Hsp70 } \\
\text { by heat-stressed carcinoembryonic antigen (CEA)- } \\
\text { positive tumor cells; possible use of exosomes as an } \\
\text { anti-cancer vaccine }\end{array}$ & exosomal surface & [139] \\
\hline \multicolumn{6}{|l|}{ Hepatocellular carcinoma } \\
\hline- & cell line & Hsp70 & - & not mentioned & [140] \\
\hline- & cell line & Hsp70 & promotion of angiogenesis, immune response & exosomal surface & [93] \\
\hline- & cell line & Hsp60, Hsp70, Hsp90 & $\begin{array}{l}\text { enhancement of exosomal Hsps release under } \\
\text { chemotherapy treatment; activation of NK cells } \\
\text { resulting in stronger antitumor immune response }\end{array}$ & exosomal surface & [129] \\
\hline- & cell line & Hsp70 & $\begin{array}{l}\text { upregulation of exosomal Hsp } 70 \text { secretion and } \\
\text { enhancement of NK-mediated immune response as a } \\
\text { result of treatment with the epigenetic drug MS-275 }\end{array}$ & exosomal surface & [94] \\
\hline
\end{tabular}


Table 1. Cont.

\begin{tabular}{|c|c|c|c|c|c|}
\hline Cancer Type & Analyzed Material & Exosomal Hsps & Clinical Values & Location & References \\
\hline- & cell lines & Hsp70 & $\begin{array}{l}\text { increase in the number of exosomes produced by } \\
\text { HCC cells and the amount of exosomal Hsp70 after } \\
\text { treatment with inhibitor of DNA methyltransferase, } \\
\text { 5-Aza-2'-deoxycytidine }\end{array}$ & not mentioned & [141] \\
\hline \multicolumn{6}{|l|}{ Thyroid cancer } \\
\hline papillary thyroid carcinoma & $\begin{array}{l}\text { human tumor tissue, } \\
\text { human plasma }\end{array}$ & Hsp27, Hsp60, Hsp90 & $\begin{array}{l}\text { possible use as plasma-derived biomarkers of tumor } \\
\text { presence/recurrence }\end{array}$ & not mentioned & [101] \\
\hline \multicolumn{6}{|l|}{ Gynecological cancer } \\
\hline $\begin{array}{l}\text { ovarian papillary } \\
\text { adenocarcinoma }\end{array}$ & human ascites aspirate & Hsp70, Hsp80 & - & not mentioned & [102] \\
\hline ovarian cancer & human urine & Hsp70 & $\begin{array}{l}\text { possible biomarker of tumor presence; correlation } \\
\text { with tumor progression }\end{array}$ & exosomal surface & [95] \\
\hline $\begin{array}{l}\text { ovarian cancer, endometrial } \\
\text { cancer }\end{array}$ & human serum & Hsp20, Hsp22 & $\begin{array}{l}\text { positive correlation with markers of cytotoxic immune } \\
\text { response (Perforin and Granzyme B); increased } \\
\text { exosomal Hsps expression in ovarian cancer patients } \\
\text { compared to endometrial cancer patients }\end{array}$ & not mentioned & [142] \\
\hline ovarian cancer & cell lines & Hsp27 & $\begin{array}{l}\text { dependence of exosomal Hsp27 release on } \\
\text { intracellular Hsp27 concentration; potential use as a } \\
\text { tumor biomarker }\end{array}$ & not mentioned & [96] \\
\hline ovarian cancer & $\begin{array}{l}\text { human blood, human } \\
\text { urine }\end{array}$ & Hsp70 & $\begin{array}{l}\text { possible use as a biomarker of tumor } \\
\text { presence/recurrence/dissemination }\end{array}$ & exosomal surface & {$[103,143,144]$} \\
\hline cervical cancer & cell line & Hsp70, Hsp90 & $\begin{array}{l}\text { interaction of exosomal Hsp70 and Hsp90 with } \\
\text { survivin }\end{array}$ & $\begin{array}{l}\text { exosomal surface, inside } \\
\text { exosomes }\end{array}$ & [145] \\
\hline \multicolumn{6}{|l|}{ Breast cancer } \\
\hline ductal adenocarcinoma & human ascites aspirate & Hsp70, Hsp80 & - & not mentioned & [102] \\
\hline- & cell line & Hsp90 9 & $\begin{array}{l}\text { increase in tumor cells motility by activating plasmin; } \\
\text { tumor progression and metastasis formation }\end{array}$ & not mentioned & [88] \\
\hline- & $\begin{array}{l}\text { human blood, human } \\
\text { urine }\end{array}$ & Hsp70 & $\begin{array}{l}\text { possible use as a biomarker of tumor } \\
\text { presence/recurrence/dissemination }\end{array}$ & exosomal surface & {$[103,143,144]$} \\
\hline- & human urine & Hsp70 & $\begin{array}{l}\text { possible biomarker of tumor presence; correlation } \\
\text { with tumor progression }\end{array}$ & exosomal surface & [95] \\
\hline adenocarcinoma & cell line & Hsp72 & $\begin{array}{l}\text { release of exosomal Hsp72 triggered by IFN- } \gamma \text { cell } \\
\text { stimulation; ability of Hsp72 to stimulate the release } \\
\text { of IL-12 by naive dendritic cells. }\end{array}$ & exosomal surface & [146] \\
\hline
\end{tabular}


Table 1. Cont.

\begin{tabular}{|c|c|c|c|c|c|}
\hline Cancer Type & Analyzed Material & Exosomal Hsps & Clinical Values & Location & References \\
\hline \multicolumn{6}{|l|}{ Lung cancer } \\
\hline adenocarcinoma & human ascites aspirate & Hsp70, Hsp80 & - & not mentioned & [102] \\
\hline - & human urine & Hsp70 & $\begin{array}{l}\text { possible biomarker of tumor presence; correlation } \\
\text { with tumor progression }\end{array}$ & exosomal surface & [95] \\
\hline - & cell line & Hsp60 & $\begin{array}{l}\text { nitration and exosomal release of Hsp60 after } \\
\text { treatment of the tumor cells with suberoylanilide } \\
\text { hydroxamic acid; possible role of exosomal Hsp60 in } \\
\text { immune stimulation }\end{array}$ & inside exosomes & [147] \\
\hline non-small cell lung cancer & human serum & Hsp70 & $\begin{array}{l}\text { correlation with response to radio- and chemotherapy; } \\
\text { correlation with osteopontin plasma levels }\end{array}$ & $\begin{array}{l}\text { lipid-bound plasma } \\
\text { Hsp70 }\end{array}$ & [148] \\
\hline non-small cell lung cancer & cell line & Hsp70, Hsp90 & $\begin{array}{l}\text { increased concentrations of } \mathrm{Hsp} 70 \text { and } \mathrm{Hsp} 90 \text { in the } \\
\text { exosomes derived from Rab27a-overexpressing tumor } \\
\text { cells; role of these exosomes in immune antitumor } \\
\text { stimulation via activation of dendritic cells }\end{array}$ & exosomal surface & [149] \\
\hline non-small cell lung cancer & cell line & Hsp70 & $\begin{array}{l}\text { induction of pro-inflammatory phenotype by } \\
\text { triggering TLR2 signaling and NF- } \mathrm{KB} \text { pathway in } \\
\text { mesenchymal stem cells; facilitating tumor growth } \\
\text { and invasion }\end{array}$ & exosomal surface & [98] \\
\hline non-small cell lung cancer & $\begin{array}{l}\text { human blood, human } \\
\text { urine }\end{array}$ & Hsp70 & $\begin{array}{l}\text { possible use as a biomarker of tumor } \\
\text { presence/recurrence/dissemination }\end{array}$ & exosomal surface & {$[103,143,144]$} \\
\hline
\end{tabular}

Abbreviations: HCC = Hepatocellular carcinoma; Hsp = Heat shock protein; IL = interleukin; NK = natural killer; TLR = Toll-like receptor. 


\section{Exosomal Heat Shock Proteins as Biomarkers of Cancer Progression and Efficacy of Anticancer Therapy in AYA}

\subsection{Central Nervous System Tumors}

Malignant CNS tumors are one of the most prevalent cancer types and the third most common cause of cancer-related death in AYA [131,150]. This heterogenous group consists of a variety of tumors; among them the major categories are gliomas, intracranial germ cell tumors and, in younger patients, embryonal tumors typical for pediatric age, such as medulloblastoma (MB). The prognosis in CNS malignancies in AYA is poorer than in children and the survival rates decrease with age [150].

The research on Hsps in malignant CNS tumors addressed mainly MB and high-grade gliomas. Various Hsps, including Hsp27, Hsp40, Hsp60, Hsp70, and Hsp90 $\alpha$ were found to be expressed in MB specimens [151,152]. One study reported that expressions of particular Hsps significantly differed between MB histological subtypes [151]. In another, Hsp90 $\beta$ was one of the proteins detected in MB, but not in benign pilocytic astrocytoma [153].

The studies on glioblastoma multiforme (GBM) confirmed the high expressions of Hsps, including Hsp27, Hsp40, Hsp60, Hsp70, Hsp72, and Hsp90 $\alpha$ in tumor specimens and GBM stem cells [154-159]. These proteins were found to be involved in pathways responsible for glioma cell invasiveness and motility and their overexpression may be associated with treatment resistance [160]. The spontaneous and radiation- or heat-shock induced release of Hsp27 and Hsp70 from glioma cells was also reported [87,161-163]. Some studies suggested the key role of extracellular Hsp90 in GBM metastasis formation [164-166]. These findings translated into in vitro and animal model studies on Hsps inhibitors and Hsp-peptide complex vaccines in GBM treatment [167-172]. Some of them recently reached the I and II phases of clinical trials [173-176].

Several studies also analyzed the role of exosomes in both pediatric and adult CNS tumors with a focus on the microRNA role $[177,178]$ and the possible use of other exosomal proteins as biomarkers $[179,180]$. However, the field of exosomal Hsps in CNS malignancies was not extensively studied.

Graner et al. were the first to report the exosomal pathway of Hsp27, Hsp60, Hsp70, and Hsp90 secretion from malignant CNS tumor cells (adult glioma and murine anaplastic astrocytoma) [87]. Later, various Hsps were detected in the proteomic analysis of extracellular vesicles released by eight glioma cell lines [136]. However, the role of exosomal release of these proteins is not fully understood. McCready et al. confirmed that exosomal Hsp90 $\alpha$ is released from various malignant cell lines, including glioma cells [88]. They also reported that, additionally to previously known mechanisms of activating matrix metalloproteinase 2 (MMP2) [81] and human epidermal growth factor receptor 2 (HER2) [181], extracellular Hsp90 $\alpha$ increases motility of the tumor cells by also activating plasmin. Interestingly, Hsp90 $\alpha$-containing exosomes enhanced the movement of the glioma cells more than Hsp90 $\alpha$ protein alone, which indicates the cooperation of Hsp90 $\alpha$ with other exosomal proteins in promoting GBM progression and metastasis formation. Another study, however, showed the antitumor immune-stimulating function of exosomes carrying Hsp70. The glioma-derived exosomes were incubated with dendritic cells, leading to stimulation of the glioma-specific cytotoxic CD8+ T-cell response [99]. Further research is needed to better understand these mechanisms and, possibly, allow one to target exosomal Hsps in experimental therapies.

\subsection{Melanoma}

Malignant melanoma (MM) is one of the most prevalent cancers in AYA, constituting $14 \%$ of all malignancies in this age group. In general, it is associated with favorable prognosis, with 5-year overall survival rates exceeding 85\% [131]. However, the biology and clinical course of MM in AYA have not been comprehensively studied. Young patients diagnosed at advanced stages of disease face specific obstacles, including lack of treatment standards and limited accessibility to clinical trials [182]. 
The aberrant expressions of Hsps, including Hsp27, Hsp40, Hsp60, Hsp70, Hsp90, and glycoprotein gp96 were reported in skin, conjunctival and uveal melanoma cells [183-191]. The expressions of Hsps were associated with clinical features of MM: worse prognosis (Hsp40 and Hsp90) [183,190,192], more advanced stage (Hsp40, Hsp60 and Hsp90) [186,190,191], and better response to treatment with bevacizumab (Hsp27) [193]. Based on these observations, some experimental studies evaluating the efficacy of Hsps inhibitors in MM treatment in vitro and on animal models were performed [183,194-197]. Some of them have been translated into clinical studies [198,199]. Immunotherapies based on tumor-derived Hsp peptide complexes (HspPCs) also reached clinical trials [200-204]. However, the role of extracellular Hsps released from MM cells in exosomes has not been extensively investigated.

Several studies detected various Hsps, including Hsp70 and Hsp90, in MM-derived exosomes [89,137]. The chaperones were more abundant in exosomes in comparison to microvesicles and apoptotic vesicles obtained from the same cell lines [138]. Exosomes containing Hsp70 and Hsp80 were also detected in malignant ascites in patients with solid tumors, including two with advanced MM [102]. The studies evaluating the role of MM-derived exosomes carrying Hsp70 yielded conflicting results. Elsner et al. found that Hsp70-overexpressing MM cells release Hsp70-positive exosomes, which in vitro activate mouse natural killer (NK) cells to kill mouse lymphoma and human melanoma cells expressing NK-activating receptors. Therefore, they suggested that Hsp70-carrying exosomes play a role in the inhibition of MM progression and dissemination [90]. Conversely, Gobbo et al. suggested that exosomal Hsp70 played a role in the inhibition of antitumor immune responses. They reported that MM-derived exosomes presenting Hsp70 on their surfaces might bind to toll-like receptor 2 (TLR2) on the myeloid-derived suppressor cells (MDSC), leading to their activation. In this study, inhibition of the extracellular domain of exosomal Hsp70 with specific peptide A8 led to the blockage of Hsp70/TLR2 association, decreasing the ability of exosomes to activate MDSCs. Consequently, treatment of melanoma-bearing mice with A8 peptide reduced the number of MDSCs in the mice spleen, inhibited MM progression and potentiated the antitumor effect of cisplatin [95].

\subsection{Colorectal Carcinoma}

Colorectal carcinoma (CRC) in AYA is rare. However, in contrary to the older patients benefiting from screening programs, the $\mathrm{CRC}$ incidence in this age group is constantly increasing. Moreover, due to experienced diagnostic delays, AYA are more likely to be diagnosed in the advanced stage of disease. The diagnosis of CRC in the young may be a sign of an underlying genetic disorder, such as familial adenomatous polyposis (FAP) or Lynch syndrome; however, most cases occur sporadically [205].

Many studies reported altered expression of various Hsps, including Hsp 20 [206], Hsp 40 [207], Hsp60 [208-210], Hsp70 [207,211], and Hsp90 [212] in the CRC specimens. The tissue Hsp status was found to be associated with tumor grade, lymph node involvement, distant metastases, response to CHT, recurrence and overall survival [206,209,212,213]. The serum concentration of Hsp60, Hsp70 and Hsp90 $\alpha$ were assessed as possible CRC biomarkers [214-217]. Consequently, several in vitro trials with Hsps inhibitors have been conducted, yielding promising results $[44,119,211,218,219]$. However, the data regarding the presence and function of Hsps in the circulating exosomes released from CRC cells is scant.

Merendino et al. for the first time reported that Hsp60 is actively released from cancer cells via the exosomal pathway $[107,108]$. These studies were based on previous research reporting increased expression of Hsp60 in preneoplastic colon lesions and CRC, suggesting its role in tumorigenesis [208-210]. Subsequently, the same research group reported the presence of Hsp60 in the exosomes obtained from the peripheral blood of patients with CRC. Hsp60 was also detected in the inflammatory natural killer (NK) cells and macrophages within the tumor microenvironment. The levels of Hsp60 in the exosomes were significantly increased at diagnosis but comparable to healthy controls after the tumor removal. Moreover, Hsp60 was detected in the membrane of exosomes before the tumor excision, but neither in the same patients after the surgery nor in healthy controls [100]. 
The authors therefore suggest that the exosomal Hsp60 blood levels could serve as a promising biomarker of CRC recurrence.

Another chaperone that was found in exosomes derived from human CRC cell lines is Hsp70 [91,95,139]. Being presented at the exosomal plasma membrane, it was found to induce natural killer (NK) lymphocyte anti-tumor activity [91]. Later, Guo et al. reported that Hsp70-rich exosomes from a mice CRC cell line also elicit an immune anti-tumor response via inducing Hsp70-dependent interleukin (IL)-6 secretion from dendritic cells. The exosomes secreted after heat stress had higher concentration of Hsp70 and were more effective immune stimulators than exosomes released spontaneously [92].

\subsection{Hepatocellular Carcinoma}

Primary hepatic malignancies are very rare in AYA. Among them, HCC predominates. In developed countries, the incidence of HCC in AYA has been constantly increasing during the last decades $[132,133]$.

HCC in AYA has distinct pathological and clinical features compared to older patients. In countries with low rates of hepatitis B virus (HBV) infections, it is usually of a fibrolamellar pathological subtype and not related to cirrhosis or underlying liver disease [220,221]. However, HCC has been observed in patients with Fanconi's syndrome and metabolic diseases (hereditary tyrosinemia, Wilson disease and glycogen storage disease type IA) [222-224]. As most patients are asymptomatic for a long time, the final diagnosis is delayed and the prognosis is poor $[131,220]$.

There are several reports about exosomes in HCC $[93,129,140,225-229]$. They suggest that exosomes may be a new biomarker in diagnosis of early-stage HCC and potential target for the treatment of this type of the tumor. However, only single studies concern exosomal Hsps and their role in the biology and aggressiveness of HCC.

Yukawa et al. detected Hsp70 expression on the surface of hepatoma G2 (HepG2) cell-derived exosomes. They confirmed that exosomal Hsp70 can be considered as significant molecules connected with angiogenesis and immune response in HCC [93]. Another study found increased release of Hsp70-containing exosomes from HCC cell lines after the treatment with an inhibitor of DNA methyltransferase, 5-Aza-2'-deoxycytidine [141]. Lv et al. reported that release of Hsp60, Hsp70, and Hsp90 was enhanced in HCC cells under antineoplastic treatment. Additionally, secretion of exosomal Hsps caused by HCC cell-resistant anticancer drugs, such as carboplatin and irinotecan hydrochloride, was remarkably higher than sensitive drugs. The authors showed that Hsps released from exosomes can trigger activity of natural killer (NK) cells resulting in augmented cytolytic activity against targeted cells and stronger immune response [129].

Another group investigated the effect of the epigenetic drug MS-275 on exosomes from HepG2 cells [94]. The study revealed that MS-275 was responsible for higher secretion of Hsp70 in exosomes, resulting in enhancement of the exosome-induced cytotoxic activity of NK cells. Findings reported by Lv et al. and Xiao et al. can contribute to the innovative and effective treatment of HCC. Notably, further efforts are required in this field, in particular, studies on the fibrolamellar subtype of HCC, characteristic for AYA patients, are lacking.

\subsection{Thyroid Cancer}

Thyroid cancer (TC) is one of the most common cancers in AYA, especially in 15-24-year-old patients [133]. In this age group, TC accounts for approximately $13 \%$ of all malignant neoplasms [230]. A significant increase in the incidence of TC has been observed in recent decades [231]. There are four histological types of TC: papillary, follicular, medullary, and anaplastic. They can develop de novo or in individuals previously treated for cancer. Medullary TC can also be present in hereditary syndromes like type 2 multiple endocrine neoplasia (MEN) syndromes MEN2A, MEN2B, and the related multigenerational familial MTC (FMTC) syndrome. 
The overall survival rate of TC is one of the highest among AYA cancers [232,233], but in anaplastic TC it is still unsatisfactory [234]. For this reason, there is a continuing need to understand the biology of thyroid cancer, find clinically useful biomarkers and develop novel therapies.

One of the promising options for therapeutic targets in TC are Hsps, which are overexpressed in thyroid malignancies. Many studies reported altered expression of various Hsps, including Hsp27 [235,236], Hsp60 [237], Hsp70 [238-242], and Hsp90 [241,243-245]. There were studies that showed that KU711 and WGA-TA, inhibitors of Hsp90, decrease migration and invasion of anaplastic TC cells in vitro. Moreover, these molecules lead to downregulation of $\beta$-catenin, BRAF, Akt, and phospho-Akt, leading to induction of apoptosis [246-248]. Kim et al. showed that apoptosis of anaplastic TC cells can be induced not only by inhibition of Hsp90, but also by Hsp70 inhibitors [247]. However, data on the role of exosomal Hsps in TC cells is scarce.

To our knowledge there is only one study on exosomal Hsps in TC. Bavisotto et al. for the first time reported significantly higher levels of Hsp27, Hsp60, and Hsp90 in tissue of papillary TC than in peritumoral tissue and non-toxic goiter. Moreover, the same Hsps were increased in exosomes obtained from plasma in patients with papillary TC. Furthermore, it was noticed that exosomal levels of Hsp27, Hsp60, and Hsp90 were higher before ablative surgery than after this procedure. These results suggest that exosomal Hsps play a role in carcinogenesis and may have clinical implications for the prognostic analysis and treatment of patients with TC. However, in the same study, no differences in Hsp70 level were found in thyroid cancer tissue and benign goiter. This is why the evaluation of Hsp70 in exosomes was not done [101]. The results obtained by the authors are interesting, but further studies are needed.

\subsection{Gynecological Cancer}

Exosomes play a significant role in intercellular female genital tract cancer interactions. They have shown immense impact on the early diagnosis, drug resistance, prognostic evaluation, metastasis and target therapies [249-251]. Exosomal proteins seem to be effective cancer biomarkers [250,252]. In gynecologic oncology, there are reports regarding tumor expression of Hsp22, Hsp27, Hsp60, Hsp70, and Hsp90 in ovarian, cervical and endometrial cancers as potential biomarkers [253]. However, there are only a few reports of exosomal HSP levels in these malignancies, mainly in ovarian cancer.

Ovarian cancer, with the high resistance to chemotherapeutic agents, remains the foremost cause of death in women globally. More than half of ovarian cancer patients are in an advanced stage at the moment of diagnosis [254] because there are no symptoms of early stage disease nor effective screening procedures. For this reason, finding a novel diagnostic method would have an impact on the treatment results.

Wyciszkiewicz et al. showed that the Hsp22 expression in peritoneal fluid samples and serum-derived exosomes in patients with ovarian cancer in comparison with endometrial cancer was higher, but the difference was statistically significant only in peritoneal fluid. They also found a positive correlation between markers of cytotoxic immune response (perforin and granzyme B) and exosomal Hsp20 and Hsp22 levels [142]. Chaperones, including Hsp70 and Hsp80, were also detected in exosomes isolated from ascites effusions in patients with advanced ovarian papillary adenocarcinoma [102]. Moreover, Stope et al. reported release of exosomal Hsp27 by ovarian cancer cell lines (OVCAR-3 and SK-OV-3). They found concentration-dependent incorporation of Hsp27 into exosomes, which suggests that Hsp27, liberated by exosomes from ovarian cancer cell lines, could serve as a noninvasive biomarker of ovarian cancer [96].

One study reported release of exosomal Hsp70 and Hsp90 from cervical cancer cells. It was suggested that these Hsps may interact with survivin, allowing for its release and intercellular transport in exosomes [145].

\subsection{Breast Cancer}

Breast cancer is the most common malignancy in women worldwide, representing about $25 \%$ of all cancers $[255,256]$. It is also the most prevalent cancer in AYA women, especially in the older 
subset of patients. Breast cancer in AYA is more often associated with familial cancer predisposition syndromes compared to older patients. Young females are also more likely to present with large tumors, unfavorable histological and molecular characteristics, and disseminated disease at diagnosis. Consequently, the outcomes in this age group are relatively unfavorable $[257,258]$.

The studies on Hsps in breast cancer revealed altered expressions of Hsp90, Hsp70 and Hsp27 in human breast cancer tissues [259-261]. Yano et al. showed that a Hsp90 $\alpha$ homolog may be involved in cell proliferation, while Hsp90ß was correlated with poor differentiated breast carcinomas [259]. Hsp27 has been also considered as a predictor for hormone sensitivity in breast cancer and also has been associated with short disease-free survival (DFS), similar to Hsp70 [260]. Heat shock proteins may be induced in response to anoxia. It has also been proven that exposure to hypoxia increases release of exosomes from breast cancer cells to promote their invasion [4,97]. However, only a few studies analyzing the role of Hsps secreted via the exosomal pathway in breast cancer have been published to date.

McCready et al. reported exosomal Hsp90 $\alpha$ presence and secretion from solid tumor cells, including breast cancer. They found that Hsp90 $\alpha$ alone does not affect tumor cell motility and invasiveness, unlike the addition of exosomes. This study is thoroughly described in the CNS tumors section [88]. Exosomes containing Hsp70 and Hsp80 were also detected in ascites fluid in two patients with advanced-stage ductal adenocarcinoma [102]. Bausero et al. reported that exosomal Hsp72 is released from breast cancer cells after interferon- $\gamma$ stimulation and may be involved in tumor surveillance mechanisms [146]. Recently, a report from a pilot study ExoDiag (NCT02662621) was published. This project aims to establish whether it is possible to identify and quantify Hsp70-exosomes in blood and urine samples in patients with solid cancers, including breast, ovarian, and non-small cell lung cancer. This could help demonstrate that exosomal Hsp70 is a valuable biomarker of tumor presence, progression or recurrence $[103,143,144]$.

\subsection{Lung Cancer}

Despite being the leading cause of cancer-related deaths in the entire population, lung cancer is exceedingly rare in AYA. Patients below 40 years of age make up only less than $1 \%$ of all lung cancer cases. In this age group, non-small cell lung cancer (NSCLC) predominates, with adenocarcinoma histology significantly more prevalent than in older adults. Probably due to better overall performance status, the prognosis in AYA with lung cancer is better than in older patients [262,263]. There are no reports of exosomal Hsps detection being performed on AYA patients' tumors. However, some more general studies on the role of exosomal Hsps in lung cancer have been published.

Campanella et al. reported that treatment of the lung carcinoma-derived cells with cytotoxic suberoylanilide hydroxamic acid (SAHA) resulted in posttranslational modification and increased exosomal release of Hsp60. They also suggested a possible role of this modified exosomal Hsp60 in immune antitumor stimulation [147]. Gobbo et al. described a higher level of exosomal Hsp70 in lung, breast and ovarian cancer patient urine samples than in healthy voluntary donors and reported exosomal Hsp70 correlation with tumor progression [95]. Exosomal Hsps were also found in malignant ascites in a patient with lung adenocarcinoma [102]. Ostheimer et al. showed a significant correlation between Hsp70 serum levels and treatment response and elevated level of osteopontin-a biomarker related to hypoxia in patients with NSCLC. Post-therapeutic plasma exosomal Hsp70 promoted a positive clinical result, defined as a better response to radio and chemotherapy. This study did not investigate exosomal Hsp70 directly; however, plasma Hsp70 was detected in two fractions: free Hsp70 and lipid-bound Hsp70, the latter corresponding to the exosomal Hsp70 [148]. Li et al. reported a relationship between lung cancer cell (A549)-derived exosomal Hsp70 presence and induction of the pro-inflammatory phenotype in mesenchymal stem cells (MSCs) by triggering TLR2 signaling and activation of the NF- $\mathrm{KB}$ pathway. This may facilitate lung cancer invasion and tumor growth [98]. Moreover, the elevated levels of Hsp70 and Hsp90 were detected in exosomes derived from Rab27a-overexpressing non-small cell lung carcinoma cells. These exosomes, via upregulating major histocompatibility complex class 
II (MHCII) and co-stimulatory molecules on dendritic cells, were found to elicit potent antitumor immune responses [149].

Engineered exosomes have been also considered as a potential cargo for specific delivery of anticancer therapeutic drugs. Exosomes being loaded with Celastrol, which inhibits Hsp90 signaling pathways, showed higher antitumor potency in lung cancer cells. [264].

\section{Conclusions and Future Directions}

Exosomes and their molecular content, including Hsps, seem to be key players in intracellular communication. Notably, they can modulate antitumor immunity and may serve as potential tumor vaccines or immunotherapeutic vesicles. The future clinical application of exosomes also includes their use as plausible biomarkers for the diagnoses, prognoses and follow-up of different diseases, including cancer [106].

Author Contributions: Conceptualization, M.A.K. and M.G.-P.; database collections M.A.K., A.P.; analysis of literature data available in the selected topic-M.A.K. and E.B.; writing-original draft preparation, M.A.K., A.P., M.S., E.B., A.M.G., A.F., S.S. and M.G.-P; writing—review and editing according to reviewers' comments, M.A.K. and M.G.-P.; graphical part-M.A.K, supervision, M.A.K. and M.G.-P.; correspondence with the editor and reviewers-M.A.K. and M.G.-P.; funding acquisition M.G.-P. All authors have read and agreed to the published version of the manuscript.

Funding: The study was supported by the Iuventus Plus project of the Polish Ministry of Science and Higher Education No. IP2015 022074.

Conflicts of Interest: The authors declare no conflict of interest.

\section{References}

1. Khalil, A.A.; Kabapy, N.F.; Deraz, S.F.; Smith, C. Heat shock proteins in oncology: Diagnostic biomarkers or therapeutic targets? Biochim. Biophys. Acta Rev. Cancer 2011, 1816, 89-104. [CrossRef] [PubMed]

2. MacArio, A.J.L.; Cappello, F.; Zummo, G.; Conway De MacArio, E. Chaperonopathies of senescence and the scrambling of interactions between the chaperoning and the immune systems. Ann. N. Y. Acad. Sci. 2010, 1197, 85-93. [CrossRef] [PubMed]

3. Rappa, F.; Farina, F.; Zummo, G.; David, S.; Campanella, C.; Carini, F.; Tomasello, G.; Damiani, P.; Cappello, F.; De Macario, E.C.; et al. HSP-Molecular chaperones in cancer biogenesis and tumor therapy: An overview. Anticancer Res. 2012, 32, 5139-5150. [PubMed]

4. Vargas-Roig, L.M.; Gago, F.E.; Tello, O.; Aznar, J.C.; Ciocca, D.R. Heat shock protein expression and drug resistance in breast cancer patients treated with induction chemotherapy. Int. J. Cancer 1998, 79, 468-475. [CrossRef]

5. Uozaki, H.; Ishida, T.; Kakiuchi, C.; Horiuchi, H.; Gotoh, T.; Iijima, T.; Imamura, T.; Machinami, R. Expression of heat shock proteins in osteosarcoma and its relationship to prognosis. Pathol. Res. Pract. 2000, 196, 665-673. [CrossRef]

6. Ciocca, D.R.; Clark, G.M.; Tandon, A.K.; Fuqua, S.A.W.; Welch, W.J.; McGuire, W.L. Heat shock protein hsp70 in patients with axillary lymph node-negative breast cancer: Prognostic implications. JNCI J. Natl. Cancer Inst. 1993, 85, 570-574. [CrossRef] [PubMed]

7. Blagosklonny, M.V. Re: Role of the heat shock response and molecular chaperones in oncogenesis and cell death. JNCI J. Natl. Cancer Inst. 2001, 93, 239-240. [CrossRef] [PubMed]

8. Van de Vijver, M.J.; He, Y.D.; van't Veer, L.J.; Dai, H.; Hart, A.A.M.; Voskuil, D.W.; Schreiber, G.J.; Peterse, J.L.; Roberts, C.; Marton, M.J.; et al. A Gene-Expression Signature as a Predictor of Survival in Breast Cancer. N. Engl. J. Med. 2002, 347, 1999-2009. [CrossRef]

9. Van't Veer, L.J.; Dai, H.; Van de Vijver, M.J.; He, Y.D.; Hart, A.A.M.; Mao, M.; Peterse, H.L.; Van Der Kooy, K.; Marton, M.J.; Witteveen, A.T.; et al. Gene expression profiling predicts clinical outcome of breast cancer. Nature 2002, 415, 530-536. [CrossRef]

10. Cornford, P.A.; Dodson, A.R.; Parsons, K.F.; Desmond, A.D.; Woolfenden, A.; Fordham, M.; Neoptolemos, J.P; Ke, Y.; Foster, C.S. Heat shock protein expression independently predicts clinical outcome in prostate cancer. Cancer Res. 2000, 60, 7099-7105. 
11. Almeida, M.B.; Do Nascimento, J.L.M.; Herculano, A.M.; Crespo-López, M.E. Molecular chaperones: Toward new therapeutic tools. Biomed. Pharmacother. 2011, 65, 239-243. [CrossRef] [PubMed]

12. Huang, L.H.; Wang, H.S.; Kang, L. Different evolutionary lineages of large and small heat shock proteins in eukaryotes. Cell Res. 2008, 18, 1074-1076. [CrossRef] [PubMed]

13. Gorska, M.; Popowska, U.; Sielicka-Dudzin, A.; Kuban-Jankowska, A.; Sawczuk, W.; Knap, N.; Cicero, G.; Bucchieri, F.; Wozniak, M. Geldanamycin and its derivatives as Hsp90 inhibitors. Front. Biosci. 2011, 17, 2269-2277. [CrossRef] [PubMed]

14. Chang, Y.S.; Lo, C.W.; Sun, F.C.; Chang, M.D.T.; Lai, Y.K. Differential expression of Hsp90 isoforms in geldanamycin-treated 9 L cells. Biochem. Biophys. Res. Commun. 2006, 344, 37-44. [CrossRef]

15. Csermely, P.; Schnaider, T.; Soti, C.; Prohászka, Z.; Nardai, G. The 90-kDa molecular chaperone family: Structure, function, and clinical applications. A comprehensive review. Pharmacol. Ther. 1998, 79, 129-168. [CrossRef]

16. Sreedhar, A.S.; Kalmár, É.; Csermely, P.; Shen, Y.F. Hsp90 isoforms: Functions, expression and clinical importance. FEBS Lett. 2004, 562, 11-15. [CrossRef]

17. Bertram, J.; Palfner, K.; Hiddemann, W.; Kneba, M. Increase of P-glycoprotein-mediated drug resistance by hsp 90ß. Anticancer Drugs 1996, 7, 838-845. [CrossRef]

18. Hanahan, D.; Weinberg, R.A. The hallmarks of cancer. Cell 2000, 100, 57-70. [CrossRef]

19. Mayer, M.P.; Bukau, B. Hsp70 chaperone systems: Diversity of cellular functions and mechanism of action. Biol. Chem. 1998, 379, 261-268.

20. Bukau, B.; Horwich, A.L. The Hsp70 and Hsp60 chaperone machines. Cell 1998, 92, 351-366. [CrossRef]

21. Kiang, J.G.; Tsokos, G.C. Heat shock protein 70 kDa: Molecular biology, biochemistry, and physiology. Pharmacol. Ther. 1998, 80, 183-201. [CrossRef]

22. Hartl, F.U. Molecular chaperones in cellular protein folding. Nature 1996, 381, 571-580. [CrossRef] [PubMed]

23. Vilasi, S.; Carrotta, R.; Mangione, M.R.; Campanella, C.; Librizzi, F.; Randazzo, L.; Martorana, V.; Gammazza, A.M.; Ortore, M.G.; Vilasi, A.; et al. Human Hsp60 with its mitochondrial import signal occurs in solution as heptamers and tetradecamers remarkably stable over a wide range of concentrations. PLoS ONE 2014, 9, e97657. [CrossRef] [PubMed]

24. Vilasi, S.; Bulone, D.; Bavisotto, C.C.; Campanella, C.; Gammazza, A.M.; San Biagio, P.L.; Cappello, F.; de Macario, E.C.; Macario, A.J.L. Chaperonin of Group I: Oligomeric spectrum and biochemical and biological implications. Front. Mol. Biosci. 2018, 4, 1-14. [CrossRef]

25. Knowlton, A.A.; Srivatsa, U. Heat-shock protein 60 and cardiovascular disease: A paradoxical role. Future Cardiol. 2008, 4, 151-161. [CrossRef] [PubMed]

26. Henderson, B.; Fares, M.A.; Lund, P.A. Chaperonin 60: A paradoxical, evolutionarily conserved protein family with multiple moonlighting functions. Biol. Rev. 2013, 88, 955-987. [CrossRef]

27. Deniset, J.F.; Hedley, T.E.; Hlaváčková, M.; Chahine, M.N.; Dibrov, E.; O’Hara, K.; Maddaford, G.G.; Nelson, D.; Maddaford, T.G.; Fandrich, R.; et al. Heat shock protein 60 involvement in vascular smooth muscle cell proliferation. Cell. Signal. 2018, 47, 44-51. [CrossRef]

28. Kirchhoff, S.R.; Gupta, S.; Knowlton, A.A. Cytosolic heat shock protein 60, apoptosis, and myocardial injury. Circulation 2002, 105, 2899-2904. [CrossRef]

29. Chandra, D.; Choy, G.; Tang, D.G. Cytosolic accumulation of HSP60 during apoptosis with or without apparent mitochondrial release: Evidence that its pro-apoptotic or pro-survival functions involve differential interactions with caspase-3. J. Biol. Chem. 2007, 282, 31289-31301. [CrossRef] [PubMed]

30. Shan, Y.X.; Liu, T.J.; Su, H.F.; Samsamshariat, A.; Mestril, R.; Wang, P.H. Hsp10 and Hsp60 modulate Bcl-2 family and mitochondria apoptosis signaling induced by doxorubicin in cardiac muscle cells. J. Mol. Cell. Cardiol. 2003, 35, 1135-1143. [CrossRef]

31. Quintana, F.J.; Cohen, I.R. The HSP60 immune system network. Trends Immunol. 2011, 32, 89-95. [CrossRef] [PubMed]

32. Calderwood, S.K.; Mambula, S.S.; Gray, P.J. Extracellular heat shock proteins in cell signaling and immunity. Ann. N. Y. Acad. Sci. 2007, 1113, 28-39. [CrossRef] [PubMed]

33. Seul-Ki, C.; Kam, H.; Kye-Young, K.; In Park, S.; Yun-Sil, L. Targeting heat shock protein 27 in cancer: A druggable target for cancer treatment? Cancers Basel 2019, 11, 1195. [CrossRef] 
34. Kokolakis, G.; Tatari, M.; Zacharopoulou, A.; Mintzas, A.C. The hsp27 gene of the Mediterranean fruit fly, Ceratitis capitata: Structural characterization, regulation and developmental expression. Insect. Mol. Biol. 2008, 17, 699-710. [CrossRef] [PubMed]

35. Delbecq, S.P.; Klevit, R.E. One size does not fit all: The oligomeric states of $\alpha \mathrm{b}$ crystallin. FEBS Lett. 2013, 587, 1073-1080. [CrossRef] [PubMed]

36. Liu, Z.; Xi, D.; Kang, M.; Guo, X.; Xu, B. Molecular cloning and characterization of Hsp27.6: The first reported small heat shock protein from Apis cerana cerana. Cell Stress Chaperones 2012, 17, 539-551. [CrossRef] [PubMed]

37. Concannon, C.G.; Gorman, A.M.; Samali, A. On the role of Hsp27 in regulating apoptosis. Apoptosis 2003, 8, 61-70. [CrossRef] [PubMed]

38. Rocchi, P.; Beraldi, E.; Ettinger, S.; Fazli, L.; Vessella, R.L.; Nelson, C.; Gleave, M. Increased Hsp27 after androgen ablation facilitates androgen-independent progression in prostate cancer via signal transducers and activators of transcription 3-mediated suppression of apoptosis. Cancer Res. 2005, 65, 11083-11093. [CrossRef] [PubMed]

39. Rocchi, P.; Jugpal, P.; So, A.; Sinneman, S.; Ettinger, S.; Fazli, L.; Nelson, C.; Gleave, M. Small interference RNA targeting heat-shock protein 27 inhibits the growth of prostatic cell lines and induces apoptosis via caspase-3 activation in vitro. BJU Int. 2006, 98, 1082-1089. [CrossRef] [PubMed]

40. Pandey, P.; Farber, R.; Nakazawa, A.; Kumar, S.; Bharti, A.; Nalin, C.; Weichselbaum, R.; Kufe, D.; Kharbanda, S. Hsp27 functions as a negative regulator of cytochrome c-dependent activation of procaspase-3. Oncogene 2000, 19, 1975-1981. [CrossRef]

41. Shiota, M.; Bishop, J.L.; Nip, K.M.; Zardan, A.; Takeuchi, A.; Cordonnier, T.; Beraldi, E.; Bazov, J.; Fazli, L.; Chi, K.; et al. Hsp27 regulates epithelial mesenchymal transition, metastasis, and circulating tumor cells in prostate cancer. Cancer Res. 2013, 73, 3109-3119. [CrossRef] [PubMed]

42. Voll, E.A.; Ogden, I.M.; Pavese, J.M.; Huang, X.K.; Xu, L.; Jovanovic, B.D.; Bergan, R.C. Heat shock protein 27 regulates human prostate cancer cell motility and metastatic progression. Oncotarget 2014, 5, 2648-2663. [CrossRef] [PubMed]

43. Ye, H.; Huang, H.; Cao, F.; Chen, M.; Zheng, X.; Zhan, R. HSPB1 Enhances SIRT2-Mediated G6PD Activation and Promotes Glioma Cell Proliferation. PLoS ONE 2016, 11, e0164285. [CrossRef] [PubMed]

44. Huang, C.-Y.; Wei, P.-L.; Chen, W.-Y.; Chang, W.-C.; Chang, Y.-J. Silencing Heat Shock Protein 27 Inhibits the Progression and Metastasis of Colorectal Cancer (CRC) by Maintaining the Stability of Stromal Interaction Molecule 1 (STIM1) Proteins. Cells 2018, 7, 262. [CrossRef]

45. Sheng, B.; Qi, C.; Liu, B.; Lin, Y.; Fu, T.; Zeng, Q. Increased HSP27 correlates with malignant biological behavior of non-small cell lung cancer and predicts patient's survival. Sci. Rep. 2017, 7, 13807. [CrossRef]

46. Ge, H.; He, X.; Guo, L.; Yang, X. Clinicopathological significance of HSP27 in gastric cancer: A meta-analysis. Onco. Targets. Ther. 2017, 10, 4543-4551. [CrossRef]

47. Tweedle, E.M.; Khattak, I.; Ang, C.W.; Nedjadi, T.; Jenkins, R.; Park, B.K.; Kalirai, H.; Dodson, A.; Azadeh, B.; Terlizzo, M.; et al. Low molecular weight heat shock protein HSP27 is a prognostic indicator in rectal cancer but not colon cancer. Gut 2010, 59, 1501-1510. [CrossRef]

48. Wu, P.-S.; Chang, Y.-H.; Pan, C.-C. High expression of heat shock proteins and heat shock factor-1 distinguishes an aggressive subset of clear cell renal cell carcinoma. Histopathology 2017, 71, 711-718. [CrossRef]

49. Feng, J.T.; Liu, Y.K.; Song, H.Y.; Dai, Z.; Qin, L.X.; Almofti, M.R.; Fang, C.Y.; Lu, H.J.; Yang, P.Y.; Tang, Z.Y. Heat-shock protein 27: A potential biomarker for hepatocellular carcinoma identified by serum proteome analysis. Proteomics 2005, 5, 4581-4588. [CrossRef]

50. Stope, M.B.; Weiss, M.; Preuss, M.; Streitbörger, A.; Ritter, C.A.; Zimmermann, U.; Walther, R.; Burchardt, M. Immediate and transient phosphorylation of the heat shock protein 27 initiates chemoresistance in prostate cancer cells. Oncol. Rep. 2014, 32, 2380-2386. [CrossRef]

51. Chauhan, D.; Li, G.; Auclair, D.; Hideshima, T.; Podar, K.; Mitsiades, N.; Mitsiades, C.; Chen, L.B.; Munshi, N.; Saxena, S.; et al. 2-Methoxyestardiol and bortezomib/proteasome-inhibitor overcome dexamethasone-resistance in multiple myeloma cells by modulating Heat Shock Protein-27. Apoptosis 2004, 9, 149-155. [CrossRef] [PubMed]

52. Kamada, M.; So, A.; Muramaki, M.; Rocchi, P.; Beraldi, E.; Gleave, M. Hsp27 knockdown using nucleotide-based therapies inhibit tumor growth and enhance chemotheraphy in human bladder cancer cells. Mol. Cancer Ther. 2007, 6, 299-308. [CrossRef] [PubMed] 
53. Zhang, D.; Putti, T.C. Over-expression of ERp29 attenuates doxorubicin-induced cell apoptosis through up-regulation of Hsp27 in breast cancer cells. Exp. Cell Res. 2010, 316, 3522-3531. [CrossRef] [PubMed]

54. Xia, Y.; Rocchi, P.; Iovanna, J.L.; Peng, L. Targeting heat shock response pathways to treat pancreatic cancer. Drug Discov. Today 2012, 17, 35-43. [CrossRef]

55. Kuramitsu, Y.; Wang, Y.; Taba, K.; Suenaga, S.; Ryozawa, S.; Kaino, S.; Sakaida, I.; Nakamura, K. Heat-shock protein 27 plays the key role in gemcitabine-resistance of pancreatic cancer cells. Anticancer Res. 2012, 32, 2295-2299.

56. Aloy, M.-T.; Hadchity, E.; Bionda, C.; Diaz-Latoud, C.; Claude, L.; Rousson, R.; Arrigo, A.-P.; Rodriguez-Lafrasse, C. Protective Role of Hsp27 Protein Against Gamma Radiation-Induced Apoptosis and Radiosensitization Effects of Hsp27 Gene Silencing in Different Human Tumor Cells. Int. J. Radiat. Oncol. 2008, 70, 543-553. [CrossRef]

57. Hadchity, E.; Aloy, M.T.; Paulin, C.; Armandy, E.; Watkin, E.; Rousson, R.; Gleave, M.; Chapet, O.; Rodriguez-Lafrasse, C. Heat shock protein 27 as a new therapeutic target for radiation sensitization of head and neck squamous cell carcinoma. Mol. Ther. 2009, 17, 1387-1394. [CrossRef]

58. Teimourian, S.; Jalal, R.; Sohrabpour, M.; Goliaei, B. Down-regulation of Hsp27 radiosensitizes human prostate cancer cells. Int. J. Urol. 2006, 13, 1221-1225. [CrossRef]

59. Fan, C.-Y.; Lee, S.; Ren, H.-Y.; Cyr, D.M. Exchangeable Chaperone Modules Contribute to Specification of Type I and Type II Hsp40 Cellular Function. Mol. Biol. Cell 2004, 15, 761-773. [CrossRef]

60. Fan, C.Y.; Lee, S.; Cyr, D.M. Mechanisms for regulation of Hsp70 function by Hsp40. Cell Stress Chaperones 2003, 8, 309-316. [CrossRef]

61. Qiu, X.B.; Shao, Y.M.; Miao, S.; Wang, L. The diversity of the DnaJ/Hsp40 family, the crucial partners for Hsp70 chaperones. Cell. Mol. Life Sci. 2006, 63, 2560-2570. [CrossRef] [PubMed]

62. Wang, C.C.; Tsai, M.F.; Hong, T.M.; Chang, G.C.; Chen, C.Y.; Yang, W.M.; Chen, J.J.W.; Yang, P.C. The transcriptional factor YY1 upregulates the novel invasion suppressor HLJ1 expression and inhibits cancer cell invasion. Oncogene 2005, 24, 4081-4093. [CrossRef] [PubMed]

63. Kurzik-Dumke, U.; Hörner, M.; Czaja, J.; Nicotra, M.R.; Simiantonaki, N.; Koslowski, M.; Natali, P.G. Progression of colorectal cancers correlates with overexpression and loss of polarization of expression of the htid-1 tumor suppressor. Int. J. Mol. Med. 2008, 21, 19-31. [CrossRef] [PubMed]

64. Lianos, G.D.; Alexiou, G.A.; Mangano, A.; Mangano, A.; Rausei, S.; Boni, L.; Dionigi, G.; Roukos, D.H. The role of heat shock proteins in cancer. Cancer Lett. 2015, 360, 114-118. [CrossRef] [PubMed]

65. Cheng, H.; Cenciarelli, C.; Nelkin, G.; Tsan, R.; Fan, D.; Cheng-Mayer, C.; Fidler, I.J. Molecular Mechanism of hTid-1, the Human Homolog of Drosophila Tumor Suppressor 1(2)Tid, in the Regulation of NF-kB Activity and Suppression of Tumor Growth. Mol. Cell. Biol. 2005, 25, 44-59. [CrossRef]

66. Semenza, G.L. The hypoxic tumor microenvironment: A driving force for breast cancer progression. Biochim. Biophys. Acta Mol. Cell Res. 2016, 1863, 382-391. [CrossRef]

67. Koong, A.C.; Denko, N.C.; Hudson, K.M.; Schindler, C.; Swiersz, L.; Koch, C.; Evans, S.; Ibrahim, H.; Le, Q.T.; Terris, D.J.; et al. Candidate genes for the hypoxic tumor phenotype. Cancer Res. 2000,60, 883-887. [CrossRef]

68. Keith, B.; Simon, M.C. Hypoxia inducible factors, stem cells and cancer. Cell 2007, 129, 465-472. [CrossRef]

69. Son, T.W.; Yun, S.P.; Yong, M.S.; Seo, B.N.; Ryu, J.M.; Youn, H.Y.; Oh, Y.M.; Han, H.J. Netrin-1 protects hypoxia-induced mitochondrial apoptosis through HSP27 expression via DCC- and integrin $\alpha 6 \beta 4$-dependent AKt, GSK-3 $\beta$, and HSF-1 in mesenchymal stem cells. Cell Death Dis. 2013, 4, 1-12. [CrossRef]

70. Patel, B.; Khaliq, A.; Jarvis-Evans, J.; Boulton, M.; Arrol, S.; Mackness, M.; McLeod, D. Hypoxia induces HSP 70 gene expression in human hepatoma (HEP G2) cells. Biochem. Mol. Biol. Int. 1995, 36, 907-912.

71. Liu, X.; Chen, S.; Tu, J.; Cai, W.; Xu, Q. HSP90 inhibits apoptosis and promotes growth by regulating HIF-1 abundance in hepatocellular carcinoma. Int. J. Mol. Med. 2016, 37, 825-835. [CrossRef] [PubMed]

72. Li, W.; Li, Y.; Guan, S.; Fan, J.; Cheng, C.F.; Bright, A.M.; Chinn, C.; Chen, M.; Woodley, D.T. Extracellular heat shock protein-90 $\alpha$ : Linking hypoxia to skin cell motility and wound healing. EMBO J. 2007, 26, 1221-1233. [CrossRef] [PubMed]

73. Murshid, A.; Eguchi, T.; Calderwood, S.K. Stress proteins in aging and life span. Int. J. Hyperth. 2013, 29, 442-447. [CrossRef] [PubMed] 
74. Krawczyk, M.A.; Styczewska, M.; Sokolewicz, E.M.; Kunc, M.; Gabrych, A.; Fatyga, A.; Izycka-Swieszewska, E.; Kazanowska, B.; Adamkiewicz-Drozynska, E.; Bien, E. Tumour expressions of hypoxic markers predict the response to neo-adjuvant chemotherapy in children with inoperable rhabdomyosarcoma. Biomarkers 2019, 24, 538-548. [CrossRef] [PubMed]

75. Guo, W.; Yang, Z.; Xia, Q.; Liu, J.; Yu, Y.; Li, J.; Zuo, Z.; Zhang, D.; Li, X.; Shi, X.; et al. Arsenite stabilizes HIF-1 $\alpha$ protein through p $85 \alpha$-mediated up-regulation of inducible Hsp70 protein expression. Cell. Mol. Life Sci. 2011, 68, 475-488. [CrossRef] [PubMed]

76. Nolan, K.D.; Franco, O.E.; Hance, M.W.; Hayward, S.W.; Isaacs, J.S. Tumor-secreted Hsp90 subverts polycomb function to drive prostate tumor growth and invasion. J. Biol. Chem. 2015, 290, 8271-8282. [CrossRef]

77. Zhou, J.; Schmid, T.; Frank, R.; Brüne, B. PI3K/Akt Is Required for Heat Shock Proteins to Protect Hypoxia-inducible Factor $1 \alpha$ from pVHL-independent Degradation. J. Biol. Chem. 2004, 279, 13506-13513. [CrossRef]

78. Filatova, A.; Seidel, S.; Böğürcü, N.; Gräf, S.; Garvalov, B.K.; Acker, T. Acidosis acts through HSP90 in a PHD/ VHL-independent manner to promote HIF function and stem cell maintenance in glioma. Cancer Res. 2016, 76, 5845-5856. [CrossRef]

79. Jayaprakash, P.; Dong, H.; Zou, M.; Bhatia, A.; O’Brien, K.; Chen, M.; Woodley, D.T.; Li, W. Hsp90 $\alpha$ and Hsp90 $\beta$ Co-Operate a Stress-Response Mechanism to Cope With Hypoxia and Nutrient Paucity during Wound Healing. J. Cell Sci. 2015, 128, 1475-1480. [CrossRef]

80. Cheng, C.-F.; Fan, J.; Fedesco, M.; Guan, S.; Li, Y.; Bandyopadhyay, B.; Bright, A.M.; Yerushalmi, D.; Liang, M.; Chen, M.; et al. Transforming Growth Factor $\alpha$ (TGF $\alpha$ )-Stimulated Secretion of HSP90 $\alpha$ : Using the Receptor LRP-1/CD91 To Promote Human Skin Cell Migration against a TGF $\beta$-Rich Environment during Wound Healing. Mol. Cell. Biol. 2008, 28, 3344-3358. [CrossRef]

81. Eustace, B.K.; Sakurai, T.; Stewart, J.K.; Yimlamai, D.; Unger, C.; Zehetmeier, C.; Lain, B.; Torella, C.; Henning, S.W.; Beste, G.; et al. Functional proteomic screens reveal an essential extracellular role for hsp90 $\alpha$ in cancer cell invasiveness. Nat. Cell Biol. 2004, 6, 507-514. [CrossRef] [PubMed]

82. Armstrong, H.K.; Gillis, J.L.; Johnson, I.R.D.; Nassar, Z.D.; Moldovan, M.; Levrier, C.; Sadowski, M.C.; Chin, M.Y.; Tomlinson Guns, E.S.; Tarulli, G.; et al. Dysregulated fibronectin trafficking by Hsp90 inhibition restricts prostate cancer cell invasion. Sci. Rep. 2018, 8, 1-14. [CrossRef] [PubMed]

83. Chalmin, F.; Ladoire, S.; Mignot, G.; Vincent, J.; Bruchard, M.; Remy-Martin, J.-P.; Boireau, W.; Rouleau, A.; Simon, B.; Lanneau, D.; et al. Membrane-associated Hsp72 from tumor-derived exosomes mediates STAT3-dependent immunosuppressive function of mouse and human myeloid-derived suppressor cells. J. Clin. Investig. 2010, 120, 457-471. [CrossRef] [PubMed]

84. Vlassov, A.V.; Magdaleno, S.; Setterquist, R.; Conrad, R. Exosomes: Current knowledge of their composition, biological functions, and diagnostic and therapeutic potentials. Biochim. Biophys. Acta Gen. Subj. 2012, 1820, 940-948. [CrossRef] [PubMed]

85. Tauro, B.J.; Greening, D.W.; Mathias, R.A.; Ji, H.; Mathivanan, S.; Scott, A.M.; Simpson, R.J. Comparison of ultracentrifugation, density gradient separation, and immunoaffinity capture methods for isolating human colon cancer cell line LIM1863-derived exosomes. Methods 2012, 56, 293-304. [CrossRef] [PubMed]

86. Pan, B.T.; Teng, K.; Wu, C.; Adam, M.; Johnstone, R.M. Electron microscopic evidence for externalization of the transferrin receptor in vesicular form in sheep reticulocytes. J. Cell Biol. 1985, 101, 942-948. [CrossRef]

87. Graner, M.W.; Cumming, R.I.; Bigner, D.D. The heat shock response and chaperones/heat shock proteins in brain tumors: Surface expression, release, and possible immune consequences. J. Neurosci. 2007, 27, 11214-11227. [CrossRef] [PubMed]

88. McCready, J.; Sims, J.D.; Chan, D.; Jay, D.G. Secretion of extracellular hsp $90 \alpha$ via exosomes increases cancer cell motility: A role for plasminogen activation. BMC Cancer 2010, 10, 294. [CrossRef]

89. Mears, R.; Craven, R.A.; Hanrahan, S.; Totty, N.; Upton, C.; Young, S.L.; Patel, P.; Selby, P.J.; Banks, R.E. Proteomic analysis of melanoma-derived exosomes by two-dimensional polyacrylamide gel electrophoresis and mass spectrometry. Proteomics 2004, 4, 4019-4031. [CrossRef]

90. Elsner, L.; Muppala, V.; Gehrmann, M.; Lozano, J.; Malzahn, D.; Bickeböller, H.; Brunner, E.; Zientkowska, M.; Herrmann, T.; Walter, L.; et al. The Heat Shock Protein HSP70 Promotes Mouse NK Cell Activity against Tumors That Express Inducible NKG2D Ligands. J. Immunol. 2007, 179, 5523-5533. [CrossRef] 
91. Gastpar, R.; Gehrmann, M.; Bausero, M.A.; Asea, A.; Gross, C.; Schroeder, J.A.; Multhoff, G. Heat shock protein 70 surface-positive tumor exosomes stimulate migratory and cytolytic activity of natural killer cells. October 2005, 65, 5238-5247. [CrossRef] [PubMed]

92. Guo, D.; Chen, Y.; Wang, S.; Yu, L.; Shen, Y.; Zhong, H.; Yang, Y. Exosomes from heat-stressed tumour cells inhibit tumour growth by converting regulatory T cells to Th17 cells via IL-6. Immunology 2018, 154, 132-143. [CrossRef] [PubMed]

93. Yukawa, H.; Suzuki, K.; Aoki, K.; Arimoto, T.; Yasui, T.; Kaji, N.; Ishikawa, T.; Ochiya, T.; Baba, Y. Imaging of angiogenesis of human umbilical vein endothelial cells by uptake of exosomes secreted from hepatocellular carcinoma cells. Sci. Rep. 2018, 8, 1-12. [CrossRef] [PubMed]

94. Xiao, W.; Dong, W.; Zhang, C.; Saren, G.; Geng, P.; Zhao, H.; Li, Q.; Zhu, J.; Li, G.; Zhang, S.; et al. Effects of the epigenetic drug MS-275 on the release and function of exosome-related immune molecules in hepatocellular carcinoma cells. Eur. J. Med. Res. 2013, 18, 1-7. [CrossRef]

95. Gobbo, J.; Marcion, G.; Cordonnier, M.; Dias, A.M.M.; Pernet, N.; Hammann, A.; Richaud, S.; Mjahed, H.; Isambert, N.; Clausse, V.; et al. Restoring Anticancer Immune Response by Targeting Tumor-Derived Exosomes with a HSP70 Peptide Aptamer. J. Natl. Cancer Inst. 2016, 108, 1-11. [CrossRef]

96. Stope, M.B.; Klinkmann, G.; Diesing, K.; Koensgen, D.; Burchardt, M.; Mustea, A. Heat shock protein HSP27 secretion by ovarian cancer cells is linked to intracellular expression levels, occurs independently of the endoplasmic reticulum pathway and HSP27's phosphorylation status, and is mediated by exosome liberation. Dis. Markers 2017, 1575374. [CrossRef]

97. King, H.W.; Michael, M.Z.; Gleadle, J.M. Hypoxic enhancement of exosome release by breast cancer cells. BMC Cancer 2012, 12,1-10. [CrossRef]

98. Li, X.; Wang, S.; Zhu, R.; Li, H.; Han, Q.; Zhao, R.C. Lung tumor exosomes induce a pro-inflammatory phenotype in mesenchymal stem cells via NFKB-TLR signaling pathway. J. Hematol. Oncol. 2016, 9, 42. [CrossRef]

99. Bu, N.; Wu, H.; Sun, B.; Zhang, G.; Zhan, S.; Zhang, R.; Zhou, L. Exosome-loaded dendritic cells elicit tumor-specific CD8 + cytotoxic T cells in patients with glioma. J. Neurooncol. 2011, 104, 659-667. [CrossRef]

100. Campanella, C.; Rappa, F.; Sciumè, C.; Marino Gammazza, A.; Barone, R.; Bucchieri, F.; David, S.; Curcurù, G.; Caruso Bavisotto, C.; Pitruzzella, A.; et al. Heat shock protein 60 levels in tissue and circulating exosomes in human large bowel cancer before and after ablative surgery. Cancer 2015, 121, 3230-3239. [CrossRef]

101. Bavisotto, C.C.; Cipolla, C.; Graceffa, G.; Barone, R.; Bucchieri, F.; Bulone, D.; Cabibi, D.; Campanella, C.; Gammazza, A.M.; Pitruzzella, A.; et al. Immunomorphological pattern of molecular chaperones in normal and pathological thyroid tissues and circulating exosomes: Potential use in clinics. Int. J. Mol. Sci. 2019, 20, 4496. [CrossRef] [PubMed]

102. Andre, F.; Schartz, N.E.C.; Movassagh, M.; Flament, C.; Pautier, P.; Morice, P.; Pomel, C.; Lhomme, C.; Escudier, B.; Le Chevalier, T.; et al. Malignant effusions and immunogenic tumour-derived exosomes. Lancet 2002, 360, 295-305. [CrossRef]

103. Chanteloup, G.; Cordonnier, M.; Isambert, N.; Bertaut, A.; Marcion, G.; Garrido, C.; Gobbo, J. Membrane-bound exosomal HSP70 as a biomarker for detection and monitoring of malignant solid tumours: A pilot study. Pilot Feasibility Stud. 2020, 6, 1-7. [CrossRef] [PubMed]

104. Théry, C.; Zitvogel, L.; Amigorena, S. Exosomes: Composition, biogenesis and function. Nat. Rev. Immunol. 2002, 2, 569-579. [CrossRef] [PubMed]

105. Théry, C.; Ostrowski, M.; Segura, E. Membrane vesicles as conveyors of immune responses. Nat. Rev. Immunol. 2009, 9, 581-593. [CrossRef] [PubMed]

106. Matsuo, H.; Chevallier, J.; Mayran, N.; Le Blanc, I.; Ferguson, C.; Fauré, J.; Blanc, N.S.; Matile, S.; Dubochet, J.; Sadoul, R.; et al. Role of LBPA and alix in multivesicular liposome formation and endosome organization. Science 2004, 303, 531-534. [CrossRef] [PubMed]

107. Merendino, A.M.; Bucchieri, F.; Campanella, C.; Marcianò, V.; Ribbene, A.; David, S.; Zummo, G.; Burgio, G.; Corona, D.F.V.; De Macario, E.C.; et al. Hsp60 is actively secreted by human tumor cells. PLoS ONE 2010, 5, e9247. [CrossRef]

108. Campanella, C.; Bucchieri, F.; Merendino, A.M.; Fucarino, A.; Burgio, G.; Corona, D.F.V.; Barbieri, G.; David, S.; Farina, F.; Zummo, G.; et al. The odyssey of Hsp60 from tumor cells to other destinations includes plasma membrane-associated stages and Golgi and exosomal protein-trafficking modalities. PLoS ONE 2012, 7, e42008. [CrossRef] 
109. Lancaster, G.I.; Febbraio, M.A. Exosome-dependent trafficking of HSP70: A novel secretory pathway for cellular stress proteins. J. Biol. Chem. 2005, 280, 23349-23355. [CrossRef]

110. Malik, Z.A.; Kott, K.S.; Poe, A.J.; Kuo, T.; Chen, L.; Ferrara, K.W.; Knowlton, A.A. Cardiac myocyte exosomes: Stability, HSP60, and proteomics. Am. J. Physiol. Hear. Circ. Physiol. 2013, 304, H954-H965. [CrossRef]

111. Tamura, Y.; Torigoe, T.; Kutomi, G.; Hirata, K.; Sato, N. New Paradigm for Intrinsic Function of Heat Shock Proteins as Endogenous Ligands in Inflammation and Innate Immunity. Curr. Mol. Med. 2012, 12, 1198-1206. [CrossRef] [PubMed]

112. Van Eden, W.; Wick, G.; Albani, S.; Cohen, I. Stress, heat shock proteins, and autoimmunity: How immune responses to heat shock proteins are to be used for the control of chronic inflammatory diseases. Ann. N. Y. Acad. Sci. 2007, 1113, 217-237. [CrossRef] [PubMed]

113. Fagone, P.; Di Rosa, M.; Palumbo, M.; De Gregorio, C.; Nicoletti, F.; Malaguarnera, L. Modulation of heat shock proteins during macrophage differentiation. Inflamm. Res. 2012, 61, 1131-1139. [CrossRef] [PubMed]

114. Nolan, K.D.; Kaur, J.; Isaacs, J.S. Secreted heat shock protein 90 promotes prostate cancer stem cell heterogeneity. Oncotarget 2017, 8, 19323-19341. [CrossRef]

115. Campanella, C.; Bucchieri, F.; Ardizzone, N.M.; Marino Gammazza, A.; Montalbano, A.; Ribbene, A.; Di Felice, V.; Bellafiore, M.; David, S.; Rappa, F.; et al. Upon oxidative stress, the antiapoptotic Hsp60/procaspase-3 complex persists in mucoepidermoid carcinoma cells. Eur. J. Histochem. 2008, 52, 221-228. [CrossRef]

116. Czarnecka, A.M.; Campanella, C.; Zummo, G.; Cappello, F. Mitochondrial chaperones in cancer: From molecular biology to clinical diagnostics. Cancer Biol. Ther. 2006, 5, 714-720. [CrossRef] [PubMed]

117. Cappello, F.; De Macario, E.C.; Marasà, L.; Zummo, G.; Macario, A.J.L. Hsp60 expression, new locations, functions and perspectives for cancer diagnosis and therapy. Cancer Biol. Ther. 2008, 7, 801-809. [CrossRef]

118. Hance, M.W.; Dole, K.; Gopal, U.; Bohonowych, J.E.; Jezierska-Drutel, A.; Neumann, C.A.; Liu, H.; Garraway, I.P.; Isaacs, J.S. Secreted Hsp90 is a novel regulator of the epithelial to mesenchymal transition (EMT) in prostate cancer. J. Biol. Chem. 2012, 287, 37732-37744. [CrossRef]

119. Nagaraju, G.P.; Long, T.E.; Park, W.; Landry, J.C.; Taliaferro-Smith, L.; Farris, A.B.; Diaz, R.; El-Rayes, B.F. Heat shock protein 90 promotes epithelial to mesenchymal transition, invasion, and migration in colorectal cancer. Mol. Carcinog. 2015, 54, 1147-1158. [CrossRef]

120. Ogorevc, E.; Kralj-Iglic, V.; Veranic, P. The role of extracellular vesicles in phenotypic cancer transformation. Radiol. Oncol. 2013, 47, 197-205. [CrossRef]

121. Keerthikumar, S.; Chisanga, D.; Ariyaratne, D.; Al Saffar, H.; Anand, S.; Zhao, K.; Samuel, M.; Pathan, M.; Jois, M.; Chilamkurti, N.; et al. ExoCarta: A web-based compendium of exosomal cargo. J. Mol. Biol. 2016, 428, 688-692. [CrossRef] [PubMed]

122. Skotland, T.; Sandvig, K.; Llorente, A. Lipids in exosomes: Current knowledge and the way forward. Prog. Lipid Res. 2017, 66, 30-41. [CrossRef] [PubMed]

123. Sato-Kuwabara, Y.; Melo, S.A.; Soares, F.A.; Calin, G.A. The fusion of two worlds: Non-coding RNAs and extracellular vesicles diagnostic and therapeutic implications (review). Int. J. Oncol. 2015, 46, 17-27. [CrossRef] [PubMed]

124. Kahlert, C.; Melo, S.A.; Protopopov, A.; Tang, J.; Seth, S.; Koch, O.; Zhang, J.; Weitz, J.; Chin, L.; Futreal, A.; et al. Identification of double-stranded genomic DNA spanning all chromosomes with mutated KRAS and p53 DNA in the serum exosomes of patients with pancreatic cancer. J. Biol. Chem. 2014, 289, 3869-3875. [CrossRef]

125. Mathivanan, S.; Fahner, C.J.; Reid, G.E.; Simpson, R.J. ExoCarta 2012: Database of exosomal proteins, RNA and lipids. Nucleic Acids Res. 2012, 40, D1241-D1244. [CrossRef]

126. Thakur, B.K.; Zhang, H.; Becker, A.; Matei, I.; Huang, Y.; Costa-Silva, B.; Zheng, Y.; Hoshino, A.; Brazier, H.; Xiang, J.; et al. Double-stranded DNA in exosomes: A novel biomarker in cancer detection. Cell Res. 2014, 24, 766-769. [CrossRef]

127. Jego, G.; Chiron, D.; Berthenet, K.; Pellat-Decceunynck, C. Modulation of normal and malignant plasma cells function by toll-like receptors. Front. Biosci. 2012, 4, 2289-2301. [CrossRef]

128. Taha, E.A.; Ono, K.; Eguchi, T. Roles of extracellular HSPs as biomarkers in immune surveillance and immune evasion. Int. J. Mol. Sci. 2019, 20, 4588. [CrossRef] 
129. Lv, L.H.; Wan, Y.L.; Lin, Y.; Zhang, W.; Yang, M.; Li, G.N.; Lin, H.M.; Shang, C.Z.; Chen, Y.J.; Min, J. Anticancer drugs cause release of exosomes with heat shock proteins from human hepatocellular carcinoma cells that elicit effective natural killer cell antitumor responses in vitro. J. Biol. Chem. 2012, 287, 15874-15885. [CrossRef]

130. Vega, V.L.; Rodríguez-Silva, M.; Frey, T.; Gehrmann, M.; Diaz, J.C.; Steinem, C.; Multhoff, G.; Arispe, N.; De Maio, A. Hsp70 Translocates into the Plasma Membrane after Stress and Is Released into the Extracellular Environment in a Membrane-Associated Form that Activates Macrophages. J. Immunol. 2008, 180, 4299-4307. [CrossRef]

131. Desandes, E.; Stark, D.P. Epidemiology of Adolescents and Young Adults with Cancer in Europe. Prog. Tumor Res. 2016, 43, 1-15. [CrossRef] [PubMed]

132. Bleyer, A.; Ferrari, A.; Whelan, J.; Barr, R.D. Global assessment of cancer incidence and survival in adolescents and young adults. Pediatr. Blood Cancer 2017, 64, 1-9. [CrossRef] [PubMed]

133. Trama, A.; Botta, L.; Steliarova-Foucher, E. Cancer Burden in Adolescents and Young Adults: A Review of Epidemiological Evidence. Cancer J. USA 2018, 24, 256-266. [CrossRef]

134. Sender, L.; Zabokrtsky, K.B. Adolescent and young adult patients with cancer: A milieu of unique features. Nat. Rev. Clin. Oncol. 2015, 12, 465-480. [CrossRef] [PubMed]

135. Barr, R.D.; Ferrari, A.; Ries, L.; Whelan, J.; Bleyer, W.A. Cancer in adolescents and young adults: A narrative review of the current status and a view of the future. JAMA Pediatr. 2016, 170, 495-501. [CrossRef]

136. Mallawaaratchy, D.M.; Hallal, S.; Russell, B.; Ly, L.; Ebrahimkhani, S.; Wei, H.; Christopherson, R.I. Comprehensive proteome profiling of glioblastoma-derived extracellular vesicles identifies markers for more aggressive disease. J. Neuro-Oncol. 2017, 131, 233-244. [CrossRef]

137. Peinado, H.; Aleckovic, M.; Lavotshkin, S.; Matei, I.; Costa-Silva, B.; Moreno-Bueno, G.; Hergueta-Redondo, M.; Williams, C.; Garcia-Santos, G.; Nitadori-Hoshino, A.; et al. Melanoma exosomes educate bone marrow progenitor cells. Nat. Med. 2012, 18, 883-891. [CrossRef]

138. Muhsin-Sharafaldine, M.R.; Saunderson, S.C.; Dunn, A.C.; Faed, J.M.; Kleffmann, T.; McLellan, A.D. Procoagulant and immunogenic properties of melanoma exosomes, microvesicles and apoptotic vesicles. Oncotarget 2016, 7, 56279-56294. [CrossRef]

139. Dai, S.; Wan, T.; Wang, B.; Zhou, X.; Xiu, F.; Chen, T.; Wu, Y.; Cao, X. More efficient induction of HLA-A*0201-restricted and carcinoembryonic antigen (CEA)—Specific CTL response by immunization with exosomes prepared from heat-stressed CEA-positive tumor cells. Clin. Cancer Res. 2005, 11, 7554-7563. [CrossRef]

140. Rao, Q.; Zuo, B.; Lu, Z.; Gao, X.; You, A.; Wu, C.; Du, Z.; Yin, H.F. Tumor-derived exosomes elicit tumor suppression in murine hepatocellular carcinoma models and humans in vitro. Hepatology 2016, 64, 456-472. [CrossRef]

141. Xiao, W.H.; Sanren, G.W.; Zhu, J.H.; Li, Q.W.; Kang, H.R.; Wang, R.L.; Song, L.P.; Ye, M. Effect of 5-Aza-2'-deoxycytidine on immune-associated proteins in exosomes from hepatoma. World J. Gastroenterol. 2010, 16, 2371-2377. [CrossRef] [PubMed]

142. Wyciszkiewicz, A.; Kalinowska-Łyszczarz, A.; Nowakowski, B.; Kaźmierczak, K.; Osztynowicz, K.; Michalak, S. Expression of small heat shock proteins in exosomes from patients with gynecologic cancers. Sci. Rep. 2019, 9, 1-9. [CrossRef] [PubMed]

143. Cordonnier, M.; Chanteloup, G.; Isambert, N.; Seigneuric, R.; Fumoleau, P.; Garrido, C.; Gobbo, J. Exosomes in cancer theranostic: Diamonds in the rough. Cell Adhes. Migr. 2017, 11, 151-163. [CrossRef] [PubMed]

144. Chanteloup, G.; Cordonnier, M.; Isambert, N.; Bertaut, A.; Hervieu, A.; Hennequin, A.; Luu, M.; Zanetta, S.; Coudert, B.; Bengrine, L.; et al. Monitoring HSP70 exosomes in cancer patients' follow up: A clinical prospective pilot study. J. Extracell. Vesicles 2020, 9. [CrossRef]

145. Khan, S.; Jutzy, J.M.S.; Aspe, J.R.; McGregor, D.W.; Neidigh, J.W.; Wall, N.R. Survivin is released from cancer cells via exosomes. Apoptosis 2011, 16,1-12. [CrossRef]

146. Bausero, M.A.; Gastpar, R.; Multhoff, G.; Asea, A. Alternative mechanism by which IFN- $\gamma$ enhances tumor recognition: Active release of heat shock protein 72. J. Immunol. 2005, 175, 2900-2912. [CrossRef]

147. Campanella, C.; D'Anneo, A.; Gammazza, A.M.; Bavisotto, C.C.; Barone, R.; Emanuele, S.; Lo Cascio, F.; Mocciaro, E.; Fais, S.; De Macario, E.C.; et al. The histone deacetylase inhibitor SAHA induces HSP60 nitration and its extracellular release by exosomal vesicles in human lung-derived carcinoma cells. Oncotarget 2016, 7, 28849-28867. [CrossRef] 
148. Ostheimer, C.; Gunther, S.; Bache, M.; Vordermark, D.; Multhoff, G. Dynamics of heat shock protein 70 serum levels as a predictor of clinical response in non-small-cell lung cancer and correlation with the hypoxia-related marker osteopontin. Front. Immunol. 2017, 8. [CrossRef]

149. Li, W.; Mu, D.; Tian, F.; Hu, Y.; Jiang, T.; Han, Y.; Chen, J.; Han, G.; Li, X. Exosomes derived from Rab27a-overexpressing tumor cells elicit efficient induction of antitumor immunity. Mol. Med. Rep. 2013, 8, 1876-1882. [CrossRef]

150. Ostrom, Q.T.; Gittleman, H.; De Blank, P.M.; Finlay, J.L.; Gurney, J.G.; McKean-Cowdin, R.; Stearns, D.S.; Wolff, J.E.; Liu, M.; Wolinsky, Y.; et al. American Brain Tumor Association Adolescent and Young Adult Primary Brain and Central Nervous System Tumors Diagnosed in the United States in 2008-2012. Neuro. Oncol. 2015, 18, i1-i50. [CrossRef]

151. Alexiou, G.A.; Vartholomatos, G.; Stefanaki, K.; Patereli, A.; Dova, L.; Karamoutsios, A.; Lallas, G.; Sfakianos, G.; Moschovi, M.; Prodromou, N. Expression of heat shock proteins in medulloblastoma. J. Neurosurg. Pediatr. 2013, 12, 452-457. [CrossRef] [PubMed]

152. Hauser, P.; Hanzély, Z.; Jakab, Z.; Oláh, L.; Szabó, E.; Jeney, A.; Schuler, D.; Fekete, G.; Bognár, L.; Garami, M. Expression and prognostic examination of heat shock proteins (HSP 27, HSP 70, and HSP 90) in medulloblastoma. J. Pediatr. Hematol. Oncol. 2006, 28, 461-466. [CrossRef]

153. Martelli, C.; Iavarone, F.; D’Angelo, L.; Arba, M.; Vincenzoni, F.; Inserra, I.; Delfino, D.; Rossetti, D.V.; Caretto, M.; Massimi, L.; et al. Integrated proteomic platforms for the comparative characterization of medulloblastoma and pilocytic astrocytoma pediatric brain tumors: A preliminary study. Mol. Biosyst. 2015, 11, 1668-1683. [CrossRef] [PubMed]

154. Alexiou, G.A.; Karamoutsios, A.; Lallas, G.; Ragos, V.; Goussia, A.; Kyritsis, A.P.; Voulgaris, S.; Vartholomatos, G. Expression of heat shock proteins in brain tumors. Turk. Neurosurg. 2014, 24, 745-749. [CrossRef] [PubMed]

155. Jiang, X.; Zhou, T.; Wang, Z.; Qi, B.; Xia, H. HSP47 Promotes Glioblastoma Stemlike Cell Survival by Modulating Tumor Microenvironment Extracellular Matrix through TGF- $\beta$ Pathway. ACS Chem. Neurosci. 2017, 8, 128-134. [CrossRef] [PubMed]

156. Kato, M.; Herz, F.; Kato, S.; Hirano, A. Expression of stress-response (heat-shock) protein 27 in human brain tumors: An immunohistochemical study. Acta Neuropathol. 1992, 83, 420-422. [CrossRef]

157. Kato, S.; Hirano, A.; Kato, M.; Herz, F.; Ohama, E. Stress-response (heat-shock) protein 72 expression in tumors of the central nervous system: An immunohistochemical investigation. Acta Neuropathol. 1992, 84, 261-264. [CrossRef]

158. Kato, S.; Kato, M.; Hirano, A.; Takikawa, M.; Ohama, E. The immunohistochemical expression of stress-response protein (srp) 60 in human brain tumours: Relationship of srp 60 to the other five srps, proliferating cell nuclear antigen and p53 protein. Histol. Histopathol. 2001, 16, 809-820. [CrossRef]

159. Hermisson, M.; Strik, H.; Rieger, J.; Dichgans, J.; Meyermann, R.; Weller, M. Expression and functional activity of heat shock proteins in human glioblastoma multiforme. Neurology 2000, 54, 1357-1364. [CrossRef]

160. Bavisotto, C.C.; Graziano, F.; Rappa, F.; Gammazza, A.M.; Logozzi, M.; Fais, S.; Maugeri, R.; Bucchieri, F.; de Macario, E.C.; Macario, A.J.L.; et al. Exosomal chaperones and miRNAs in gliomagenesis: State-of-art and theranostics perspectives. Int. J. Mol. Sci. 2018, 19, 2626. [CrossRef]

161. Thorsteinsdottir, J.; Stangl, S.; Fu, P.; Guo, K.; Albrecht, V.; Eigenbrod, S.; Erl, J.; Gehrmann, M.; Tonn, J.C.; Multhoff, G.; et al. Overexpression of cytosolic, plasma membrane bound and extracellular heat shock protein 70 (Hsp70) in primary glioblastomas. J. Neurooncol. 2017, 135, 443-452. [CrossRef] [PubMed]

162. Guzhova, I.; Kislyakova, K.; Moskaliova, O.; Fridlanskaya, I.; Tytell, M.; Cheetham, M.; Margulis, B. In vitro studies show that Hsp70 can be released by glia and that exogenous Hsp70 can enhance neuronal stress tolerance. Brain Res. 2001, 914, 66-73. [CrossRef]

163. Pasi, F.; Paolini, A.; Nano, R.; Di Liberto, R.; Capelli, E. Effects of single or combined treatments with radiation and chemotherapy on survival and danger signals expression in glioblastoma cell lines. Biomed Res. Int. 2014. [CrossRef] [PubMed]

164. Gopal, U.; Bohonowych, J.E.; Lema-Tome, C.; Liu, A.; Garrett-Mayer, E.; Wang, B.; Isaacs, J.S. A novel extracellular Hsp90 mediated co-receptor function for LRP1 regulates EphA2 dependent glioblastoma cell invasion. PLoS ONE 2011, 6, e17649. [CrossRef] [PubMed] 
165. Thuringer, D.; Hammann, A.; Benikhlef, N.; Fourmaux, E.; Bouchot, A.; Wettstein, G.; Solary, E.; Garrido, C. Transactivation of the epidermal growth factor receptor by heat shock protein 90 via toll-like receptor 4 contributes to the migration of glioblastoma cells. J. Biol. Chem. 2011, 286, 3418-3428. [CrossRef] [PubMed]

166. Snigireva, A.V.; Vrublevskaya, V.V.; Skarga, Y.Y.; Morenkov, O.S. Cell surface heparan sulfate proteoglycans are involved in the extracellular Hsp90-stimulated migration and invasion of cancer cells. Cell Stress Chaperones 2019, 24, 309-322. [CrossRef] [PubMed]

167. Ampie, L.; Choy, W.; Lamano, J.B.; Fakurnejad, S.; Bloch, O.; Parsa, A.T. Heatshock protein vaccines against Glioblastoma: From bench to bedside. J. Neuro-Oncol. 2016, 123, 441-448. [CrossRef]

168. Canella, A.; Welker, A.M.; Yoo, J.Y.; Xu, J.; Abas, F.S.; Kesanakurti, D.; Nagarajan, P.; Beattie, C.E.; Sulman, E.P.; Liu, J.; et al. Efficacy of Onalespib a Long-acting Second Generation HSP90 Inhibitor as a Single Agent and in Combination with Temozolomide against Malignant Gliomas. Clin. Cancer Res. 2017, 23, 6215-6226. [CrossRef]

169. Gaspar, N.; Sharp, S.Y.; Eccles, S.A.; Gowan, S.; Popov, S.; Jones, C.; Pearson, A.; Vassal, G.; Workman, P. Mechanistic evaluation of the novel HSP90 inhibitor NVP-AUY922 in adult and pediatric glioblastoma. Mol. Cancer Ther. 2010, 9, 1219-1233. [CrossRef]

170. Sauvageot, C.M.-E.; Weatherbee, J.L.; Kesari, S.; Winters, S.E.; Barnes, J.; Dellagatta, J.; Ramakrishna, N.R.; Stiles, C.D.; Kung, A.L.-J.; Kieran, M.W.; et al. Efficacy of the HSP90 inhibitor 17-AAG in human glioma cell lines and tumorigenic glioma stem cells. Neuro. Oncol. 2009, 11, 109-121. [CrossRef]

171. Wu, J.; Wang, W.; Shao, Q.; Xiao, G.; Cheng, J.; Yuan, Y.; Zhang, M. Irradiation facilitates the inhibitory effect of the heat shock protein 90 inhibitor NVP-BEP800 on the proliferation of malignant glioblastoma cells through attenuation of the upregulation of heat shock protein 70. Exp. Ther. Med. 2014, 8, 893-898. [CrossRef] [PubMed]

172. Ohba, S.; Hirose, Y.; Yoshida, K.; Yazaki, T.; Kawase, T. Inhibition of 90-kD heat shock protein potentiates the cytotoxicity of chemotherapeutic agents in human glioma cells. Laboratory investigation. J. Neurosurg. 2010, 112, 33-42. [CrossRef] [PubMed]

173. Ji, N.; Zhang, Y.; Liu, Y.; Xie, J.; Wang, Y.; Hao, S.; Gao, Z. Heat shock protein peptide complex-96 vaccination for newly diagnosed glioblastoma: A phase I, single-arm trial. JCI Insight 2018, 3, 1-9. [CrossRef] [PubMed]

174. Bloch, O.; Crane, C.A.; Fuks, Y.; Kaur, R.; Aghi, M.K.; Berger, M.S.; Butowski, N.A.; Chang, S.M.; Clarke, J.L.; McDermott, M.W.; et al. Heat-shock protein peptide complex-96 vaccination for recurrent glioblastoma: A phase II, single-arm trial. Neuro. Oncol. 2014, 16, 274-279. [CrossRef] [PubMed]

175. Bloch, O.; Lim, M.; Sughrue, M.E.; Komotar, R.J.; Abrahams, J.M.; Rourke, D.M.O.; Ambrosio, A.D.; Bruce, J.N.; Parsa, A.T. Autologous Heat Shock Protein Peptide Vaccination for Newly Diagnosed Glioblastoma: Impact of Peripheral PD-L1 Expression on Response to Therapy. Clin. Cancer Res. 2017, 23, 3575-3584. [CrossRef] [PubMed]

176. Crane, C.A.; Han, S.J.; Ahn, B.; Oehlke, J.; Kivett, V.; Fedoroff, A.; Butowski, N.; Chang, S.M.; Clarke, J.; Berger, M.S.; et al. Individual patient-specific immunity against high-grade glioma after vaccination with autologous tumor derived peptides bound to the 96 KD chaperone protein. Clin. Cancer Res. 2013, 19, 205-214. [CrossRef] [PubMed]

177. Tuzesi, A.; Kling, T.; Wenger, A.; Lunavat, T.R.; Jang, S.C.; Rydenhag, B.; Lötvall, J.; Pollard, S.M.; Danielsson, A.; Carén, H. Pediatric brain tumor cells release exosomes with a miRNA repertoire that differs from exosomes secreted by normal cells. Oncotarget 2017, 8, 90164-90175. [CrossRef]

178. Skog, J.; Wurdinger, T.; van Rijn, S.; Meijer, D.; Gainche, L.; Sena-Esteves, M.; Curry, W.T., Jr.; Carter, R.S.; Krichevsky, A.M.; Breakefield, X.O. Glioblastoma microvesicles transport RNA and protein that promote tumor growth and provide diagnostic biomarkers. Nat. Cell Biol. 2008, 10, 1470-1476. [CrossRef]

179. Yang, J.; Song, J.; Huo, H.; Zhao, Y.; Zhang, G.; Zhao, Z.; Sun, G.; Jiao, B. DNM3, p65 and p53 from exosomes represent potential clinical diagnosis markers for glioblastoma multiforme Jian-kai. Ther. Adv. Med. Oncol. 2017, 9, 741-754. [CrossRef]

180. Saadatpour, L.; Fadaee, E.; Fadaei, S.; Nassiri Mansour, R.; Mohammadi, M.; Mousavi, S.M.; Goodarzi, M.; Verdi, J.; Mirzaei, H. Glioblastoma: Exosome and microRNA as novel diagnosis biomarkers. Cancer Gene Ther. 2016, 23, 415-418. [CrossRef]

181. Sidera, K.; Gaitanou, M.; Stellas, D.; Matsas, R.; Patsavoudi, E. A critical role for HSP90 in cancer cell invasion involves interaction with the extracellular domain of HER-2. J. Biol. Chem. 2008, 283, 2031-2041. [CrossRef] [PubMed] 
182. Indini, A.; Brecht, I.; Del Vecchio, M.; Sultan, I.; Signoroni, S.; Ferrari, A. Cutaneous melanoma in adolescents and young adults. Pediatr. Blood Cancer 2018, 65, 1-6. [CrossRef] [PubMed]

183. Faingold, D.; Marshall, J.C.; Antecka, E.; Di Cesare, S.; Odashiro, A.N.; Bakalian, S.; Fernandes, B.F.; Burnier, M.N. Immune expression and inhibition of heat shock protein 90 in uveal melanoma. Clin. Cancer Res. 2008, 14, 847-855. [CrossRef]

184. Becker, B.; Multhoff, G.; Farkas, B.; Wild, P.J.; Landthaler, M.; Stolz, W.; Vogt, T. Induction of Hsp90 protein expression in malignant melanomas and melanoma metastases. Exp. Dermatol. 2004, 13, 27-32. [CrossRef] [PubMed]

185. Missotten, G.S.; Journée-de Korver, J.G.; De Wolff-Rouendaal, D.; Keunen, J.E.; Schlingemann, R.O.; Jager, M.J. Heat shock protein expression in the eye and in uveal melanoma. Investig. Ophthalmol. Vis. Sci. 2003, 44, 3059-3065. [CrossRef] [PubMed]

186. Nájera, L.; Alonso-Juarranz, M.; Garrido, M.; Ballestín, C.; Moya, L.; Martínez-Díaz, M.; Carrillo, R.; Juarranz, A.; Rojo, F.; Cuezva, J.M.; et al. Prognostic implications of markers of the metabolic phenotype in human cutaneous melanoma. Br. J. Dermatol. 2019, 181, 114-127. [CrossRef]

187. Westekemper, H.; Karimi, S.; Süsskind, D.; Anastassiou, G.; Freistühler, M.; Steuhl, K.P.; Bornfeld, N.; Schmid, K.W.; Grabellus, F. Expression of HSP 90, PTEN and Bcl-2 in conjunctival melanoma. Br. J. Ophthalmol. 2011, 95, 853-858. [CrossRef]

188. Park, H.S.; Park, C.H.; Choi, B.R.; Lim, M.S.; Heo, S.H.; Kim, C.H.; Kang, S.G.; Whang, K.U.; Cho, M.K. Expression of heat shock protein 105 and 70 in malignant melanoma and benign melanocytic nevi. J. Cutan. Pathol. 2009, 36, 511-516. [CrossRef]

189. Strickler, A.G.; Vasquez, J.G.; Yates, N.; Ho, J. Potential diagnostic significance of HSP90, ACS/TMS1, and L-plastin in the identification of melanoma. Melanoma Res. 2014, 24, 535-544. [CrossRef]

190. Shipp, C.; Weide, B.; Derhovanessian, E.; Pawelec, G. Hsps are up-regulated in melanoma tissue and correlate with patient clinical parameters. Cell Stress Chaperones 2013, 18, 145-154. [CrossRef]

191. McCarthy, M.M.; Pick, E.; Kluger, Y.; Gould-Rothberg, B.; Lazova, R.; Camp, R.L.; Rimm, D.L.; Kluger, H.M. HSP90 as a marker of progression in melanoma. Ann. Oncol. 2008, 19, 590-594. [CrossRef] [PubMed]

192. Košec, A.; Novak, R.; Konjevoda, P.; Trkulja, V.; Bedeković, V.; Grgurević, L. Tumor tissue hnRNP M and HSP $90 \alpha$ as potential predictors of disease-specific mortality in patients with early-stage cutaneous head and neck melanoma: A proteomics-based study. Oncotarget 2019, 10, 6713-6722. [CrossRef] [PubMed]

193. Schuster, C.; Akslen, L.A.; Straume, O. Expression of Heat Shock Protein 27 in melanoma metastases is associated with overall response to bevacizumab monotherapy: Analyses of predictive markers in a clinical phase II study. PLoS ONE 2016, 11, e0155242. [CrossRef]

194. Wu, X.; Marmarelis, M.E.; Hodi, F.S. Activity of the Heat Shock Protein 90 Inhibitor Ganetespib in Melanoma. PLoS ONE 2013, 8, e56134. [CrossRef] [PubMed]

195. Shin, M.K.; Jeong, K.H.; Choi, H.; Ahn, H.J.; Lee, M.H. Heat shock protein 90 inhibitor enhances apoptosis by inhibiting the AKT pathway in thermal-stimulated SK-MEL-2 human melanoma cell line. J. Dermatol. Sci. 2018, 90, 357-360. [CrossRef]

196. Liu, K.S.; Ding, W.C.; Wang, S.X.; Liu, Z.; Xing, G.W.; Wang, Y.; Wang, Y.F. The heat shock protein 90 inhibitor SNX-2112 inhibits B16 melanoma cell growth in vitro and in vivo. Oncol. Rep. 2012, 27, 1904-1910. [CrossRef]

197. Schmitt, E.; Maingret, L.; Puig, P.E.; Rerole, A.L.; Ghiringhelli, F.; Hammann, A.; Solary, E.; Kroemer, G.; Garrido, C. Heat shock protein 70 neutralization exerts potent antitumor effects in animal models of colon cancer and melanoma. Cancer Res. 2006, 66, 4191-4197. [CrossRef]

198. Eroglu, Z.; Chen, Y.A.; Gibney, G.T.; Weber, J.S.; Kudchadkar, R.R.; Khushalani, N.I.; Markowitz, J.; Brohl, A.S.; Tetteh, L.F.; Ramadan, H.; et al. Combined BRAF and HSP90 inhibition in patients with unresectable BRAF V600E mutant melanoma. Clin. Cancer Res. 2018, 24, 5516-5524. [CrossRef]

199. Shah, S.; Luke, J.J.; Jacene, H.A.; Chen, T.; Giobbie-Hurder, A.; Ibrahim, N.; Buchbinder, E.L.; McDermott, D.F.; Flaherty, K.T.; Sullivan, R.J.; et al. Results from phase II trial of HSP90 inhibitor, STA-9090 (ganetespib), in metastatic uveal melanoma. Melanoma Res. 2018, 28, 605-610. [CrossRef]

200. Tosti, G.; Cocorocchio, E.; Pennacchioli, E.; Ferrucci, P.F.; Testori, A.; Martinoli, C. Heat-shock proteins-based immunotherapy for advanced melanoma in the era of target therapies and immunomodulating agents. Expert Opin. Biol. Ther. 2014, 14, 955-967. [CrossRef] 
201. Eton, O.; Ross, M.I.; East, M.J.; Mansfield, P.F.; Papadopoulos, N.; Ellerhorst, J.A.; Bedikian, A.Y.; Lee, J.E. Autologous tumor-derived heat-shock protein peptide complex-96 (HSPPC-96) in patients with metastatic melanoma. J. Transl. Med. 2010, 8, 1-13. [CrossRef] [PubMed]

202. Belli, F.; Testori, A.; Rivoltini, L.; Maio, M.; Andreola, G.; Sertoli, M.R.; Gallino, G.; Piris, A.; Cattelan, A.; Lazzari, I.; et al. Vaccination of metastatic melanoma patients with autologous tumor-derived heat shock protein gp96-peptide complexes: Clinical and immunologic findings. J. Clin. Oncol. 2002, 20, 4169-4180. [CrossRef] [PubMed]

203. Testori, A.; Richards, J.; Whitman, E.; Mann, G.B.; Lutzky, J.; Camacho, L.; Parmiani, G.; Tosti, G.; Kirkwood, J.M.; Hoos, A.; et al. Phase III comparison of vitespen, an autologous tumor-derived heat shock protein gp96 peptide complex vaccine, with physician's choice of treatment for stage IV melanoma: The C-100-21 study group. J. Clin. Oncol. 2008, 26, 955-962. [CrossRef] [PubMed]

204. Pilla, L.; Patuzzo, R.; Rivoltini, L.; Maio, M.; Pennacchioli, E.; Lamaj, E.; Maurichi, A.; Massarut, S.; Marchianò, A.; Santantonio, C.; et al. A phase II trial of vaccination with autologous, tumor-derived heat-shock protein peptide complexes Gp96, in combination with GM-CSF and interferon- $\alpha$ in metastatic melanoma patients. Cancer Immunol. Immunother. 2006, 55, 958-968. [CrossRef]

205. Levine, O.; Zbuk, K. Colorectal cancer in adolescents and young adults: Defining a growing threat. Pediatr. Blood Cancer 2019, 66, e27941. [CrossRef]

206. Ju, Y.T.; Kwag, S.J.; Park, H.J.; Jung, E.J.; Jeong, C.Y.; Jeong, S.H.; Lee, Y.J.; Choi, S.K.; Kang, K.R.; Hah, Y.S.; et al. Decreased expression of heat shock protein 20 in colorectal cancer and its implication in Tumorigenesis. J. Cell. Biochem. 2015, 116, 277-286. [CrossRef] [PubMed]

207. Kanazawa, Y.; Isomoto, H.; Oka, M.; Yano, Y.; Soda, H.; Shikuwa, S.; Takeshima, F.; Omagari, K.; Mizuta, Y.; Murase, K.; et al. Expression of heat shock protein (Hsp) 70 and Hsp 40 in colorectal cancer. Med. Oncol. 2003, 20, 157-164. [CrossRef]

208. Cappello, F.; Bellafiore, M.; Palma, A.; David, S.; Marcianò, V.; Bartolotta, T.; Sciumè, C.; Modica, G.; Farina, F.; Zummo, G.; et al. 60KDa chaperonin (HSP60) is over-expressed during colorectal carcinogenesis. Eur. J. Histochem. 2003, 47, 105-109. [CrossRef]

209. Cappello, F.; David, S.; Rappa, F.; Bucchieri, F.; Marasà, L.; Bartolotta, T.E.; Farina, F.; Zummo, G. The expression of Hsp60 and Hsp10 in large bowel carcinomas with lymph node metastases. BMC Cancer 2005, 5, 1-10. [CrossRef]

210. He, Y.; Wu, Y.; Mou, Z.; Li, W.; Zou, L.; Fu, T.; Zhang, A.; Xiang, D.; Xiao, H.; Wang, X. Proteomics-based identification of HSP60 as a tumor-associated antigen in colorectal cancer. Proteom.- Clin. Appl. 2007, 1, 336-342. [CrossRef]

211. Jagadish, N.; Parashar, D.; Gupta, N.; Agarwal, S.; Suri, V.; Kumar, R.; Suri, V.; Sadasukhi, T.C.; Gupta, A.; Ansari, A.S.; et al. Heat shock protein 70-2 (HSP70-2) is a novel therapeutic target for colorectal cancer and is associated with tumor growth. BMC Cancer 2016, 16, 1-13. [CrossRef] [PubMed]

212. Drecoll, E.; Nitsche, U.; Bauer, K.; Berezowska, S.; Slotta-Huspenina, J.; Rosenberg, R.; Langer, R. Expression analysis of heat shock protein 90 (HSP90) and Her2 in colon carcinoma. Int. J. Colorectal Dis. 2014, 29, 663-671. [CrossRef] [PubMed]

213. Choi, D.H.; Ha, J.S.; Lee, W.H.; Song, J.K.; Kim, G.Y.; Park, J.H.; Cha, H.J.; Lee, B.J.; Park, J.W. Heat shock protein 27 is associated with irinotecan resistance in human colorectal cancer cells. FEBS Lett. 2007, 581, 1649-1656. [CrossRef] [PubMed]

214. Gunaldi, M.; Kocoglu, H.; Okuturlar, Y.; Gedikbasi, A.; Karabulut, M.; Alis, H.; Hursitoglu, M. Heat shock protein 70 is a useful marker for predicting colorectal cancer. J. BUON 2015, 20, 1464-1470. [PubMed]

215. Hamelin, C.; Cornut, E.; Poirier, F.; Pons, S.; Beaulieu, C.; Charrier, J.P.; Haïdous, H.; Cotte, E.; Lambert, C.; Piard, F.; et al. Identification and verification of heat shock protein 60 as a potential serum marker for colorectal cancer. FEBS J. 2011, 278, 4845-4859. [CrossRef]

216. Kasanga, M.; Liu, L.; Xue, L.; Song, X. Serum heat shock protein $90 \alpha$ have an advantage in diagnosis of colorectal cancer at early stage. Biomark. Med. 2018, 12, 881-890. [CrossRef] [PubMed]

217. Kocsis, J.; Madaras, B.; Tóth, É.K.; Füst, G.; Prohászka, Z. Serum level of soluble 70-kD heat shock protein is associated with high mortality in patients with colorectal cancer without distant metastasis. Cell Stress Chaperones 2010, 15, 143-151. [CrossRef] 
218. Dinić, J.; Podolski-Renić, A.; Jovanović, M.; Musso, L.; Tsakovska, I.; Pajeva, I.; Dallavalle, S.; Pešić, M. Novel heat shock protein 90 inhibitors suppress P-glycoprotein activity and overcome multidrug resistance in cancer cells. Int. J. Mol. Sci. 2019, 20, 4575. [CrossRef]

219. Moradi-Marjaneh, R.; Paseban, M.; Moradi Marjaneh, M. Hsp70 inhibitors: Implications for the treatment of colorectal cancer. IUBMB Life 2019, 71, 1834-1845. [CrossRef]

220. Chaudhari, V.A.; Khobragade, K.; Bhandare, M.; Shrikhande, S.V. Management of fibrolamellar hepatocellular carcinoma. Chinese Clin. Oncol. 2018, 7. [CrossRef]

221. Riggle, K.M.; Turnham, R.; Scott, J.D.; Yeung, R.S.; Riehle, K.J. Fibrolamellar Hepatocellular Carcinoma: Mechanistic Distinction From Adult Hepatocellular Carcinoma. Pediatr. Blood Cancer 2016, 63, 1163-1167. [CrossRef] [PubMed]

222. Emre, S.; McKenna, G.J. Liver tumors in children. Pediatr. Transplant. 2004, 8, 632-638. [CrossRef] [PubMed]

223. Franco, L.M.; Krishnamurthy, V.; Bali, D.; Weinstein, D.A.; Arn, P.; Clary, B.; Boney, A.; Sullivan, J.; Frush, D.P.; Chen, Y.T.; et al. Hepatocellular carcinoma in glycogen storage disease type Ia: A case series. J. Inherit. Metab. Dis. 2005, 28, 153-162. [CrossRef] [PubMed]

224. Gunjan, D.; Shalimar; Nadda, N.; Kedia, S.; Nayak, B.; Paul, S.B.; Gamanagatti, S.R.; Acharya, S.K. Hepatocellular Carcinoma: An Unusual Complication of Longstanding Wilson Disease. J. Clin. Exp. Hepatol. 2017, 7, 152-154. [CrossRef] [PubMed]

225. He, M.; Qin, H.; Poon, T.C.W.; Sze, S.C.; Ding, X.; Co, N.N.; Ngai, S.M.; Chan, T.F.; Wong, N. Hepatocellular carcinoma-derived exosomes promote motility of immortalized hepatocyte through transfer of oncogenic proteins and RNAs. Carcinogenesis 2015, 36, 1008-1018. [CrossRef]

226. Wang, S.; Chen, G.; Lin, X.; Xing, X.; Cai, Z.; Liu, X.; Liu, J. Role of exosomes in hepatocellular carcinoma cell mobility alteration. Oncol. Lett. 2017, 14, 8122-8131. [CrossRef] [PubMed]

227. Zhang, J.; Lu, S.; Zhou, Y.; Meng, K.; Chen, Z.; Cui, Y.; Shi, Y.; Wang, T.; He, Q.Y. Motile hepatocellular carcinoma cells preferentially secret sugar metabolism regulatory proteins via exosomes. Proteomics 2017, 17, 13-14. [CrossRef]

228. Wang, S.; Xu, M.; Li, X.; Su, X.; Xiao, X.; Keating, A.; Zhao, R.C. Exosomes released by hepatocarcinoma cells endow adipocytes with tumor-promoting properties. J. Hematol. Oncol. 2018, 11, 1-14. [CrossRef]

229. Sasaki, R.; Kanda, T.; Yokosuka, O.; Kato, N.; Matsuoka, S.; Moriyama, M. Exosomes and hepatocellular carcinoma: From bench to bedside. Int. J. Mol. Sci. 2019, 20, 1406. [CrossRef] [PubMed]

230. Massimino, M.; Evans, D.B.; Podda, M.; Spinelli, C.; Collini, P.; Pizzi, N.; Bleyer, A. Thyroid cancer in adolescents and young adults. Pediatr. Blood Cancer 2018, 65, 1-9. [CrossRef]

231. Seib, C.D.; Sosa, J.A. Evolving Understanding of the Epidemiology of Thyroid Cancer. Endocrinol. Metab. Clin. N. Am. 2019, 48, 23-35. [CrossRef] [PubMed]

232. Gatta, G.; Capocaccia, R.; Stiller, C.; Kaatsch, P.; Berrino, F.; Terenziani, M. Childhood cancer survival trends in Europe: A EUROCARE working group study. J. Clin. Oncol. 2005, 23, 3742-3751. [CrossRef] [PubMed]

233. Collini, P.; Massimino, M.; Leite, S.F.; Mattavelli, F.; Seregni, E.; Zucchini, N.; Spreafico, F.; Ferrari, A.; Castellani, M.R.; Cantù, G.; et al. Papillary thyroid carcinoma of childhood and adolescence: A 30-year experience at the istituto nazionale tumori in Milan. Pediatr. Blood Cancer 2006, 46, 300-306. [CrossRef] [PubMed]

234. Patel, K.N.; Shaha, A.R. Poorly differentiated and anaplastic thyroid cancer. Cancer Control 2006, 13, 119-128. [CrossRef]

235. Mo, X.M.; Li, L.; Zhu, P.; Dai, Y.J.; Zhao, T.T.; Liao, L.Y.; Chen, G.G.; Liu, Z.M. Up-regulation of Hsp27 by $\mathrm{ER} \alpha / \mathrm{Sp} 1$ facilitates proliferation and confers resistance to apoptosis in human papillary thyroid cancer cells. Mol. Cell. Endocrinol. 2016, 431, 71-87. [CrossRef]

236. Wang, S.; Yang, S.; Vlantis, A.C.; Liu, S.Y.W.; Ng, E.K.W.; Chan, A.B.W.; Wu, J.; Du, J.; Wei, W.; Liu, X.; et al. Expression of Antioxidant Molecules and Heat Shock Protein 27 in Thyroid Tumors. J. Cell. Biochem. 2016, 2481, 2473-2481. [CrossRef]

237. Park, W.S.; Chung, K.-W.; Young, M.S.; Kim, S.-K.; Lee, Y.J.; Lee, E.K. Differential protein expression of lymph node metastases of papillary thyroid carcinoma harboring the BRAF mutation. Anticancer Res. 2013, 33, 4357-4364.

238. Abdullah, M.I.; Lee, C.C.; Mat Junit, S.; Ng, K.L.; Hashim, O.H. Tissue and serum samples of patients with papillary thyroid cancer with and without benign background demonstrate different altered expression of proteins. PeerJ 2016, 4, e2450. [CrossRef] 
239. Fouad, E.M.; Harb, O.A.; Salem, R.A.; El Farargy, O.M.; Habib, F.M.; Gertallah, L.M. The expression of FOXE-1 and STIP-1 in papillary thyroid carcinoma and their relationship with patient prognosis. Iran. J. Pathol. 2018, 13, 256-271. [CrossRef]

240. Mo, J.-H.; Choi, I.J.; Jeong, W.-J.; Jeon, E.-H.; Ahn, S.-H. HIF-1 $\alpha$ and HSP90: Target molecules selected from a tumorigenic papillary thyroid carcinoma cell line. Cancer Sci. 2012, 103, 464-471. [CrossRef]

241. Soudry, E.; Stern Shavit, S.; Hardy, B.; Morgenstern, S.; Hadar, T.; Feinmesser, R. Heat shock proteins HSP90, HSP70 and GRP78 expression in medullary thyroid carcinoma. Ann. Diagn. Pathol. 2017, 26, 52-56. [CrossRef] [PubMed]

242. Yuan, M.H.; Zhou, R.S.; She, B.; Xu, H.F.; Wang, J.Y.; Wei, L.X. Expression and clinical significance of STIP1 in papillary thyroid carcinoma. Tumor Biol. 2014, 35, 2391-2395. [CrossRef] [PubMed]

243. Song, H.Y.; Dunbar, J.D.; Zhang, Y.X.; Guo, D.; Donner, D.B. Identification of a protein with homology to hsp90 that binds the type 1 tumor necrosis factor receptor. J. Biol. Chem. 1995, 270, 3574-3581. [CrossRef] [PubMed]

244. Felts, S.J.; Owen, B.A.L.; Nguyen, P.M.; Trepel, J.; Donner, D.B.; Toft, D.O. The hsp90-related protein TRAP1 is a mitochondrial protein with distinct functional properties. J. Biol. Chem. 2000, 275, 3305-3312. [CrossRef] [PubMed]

245. Palladino, G.; Notarangelo, T.; Pannone, G.; Piscazzi, A.; Lamacchia, O.; Sisinni, L.; Spagnoletti, G.; Toti, P.; Santoro, A.; Storto, G.; et al. TRAP1 regulates cell cycle and apoptosis in thyroid carcinoma cells. Endocr. Relat. Cancer 2016, 23, 699-709. [CrossRef]

246. Liu, J.; Sun, W.; Dong, W.; Wang, Z.; Qin, Y.; Zhang, T.; Zhang, H. HSP90 inhibitor NVP-AUY922 induces cell apoptosis by disruption of the survivin in papillary thyroid carcinoma cells. Biochem. Biophys. Res. Commun. 2017, 487, 313-319. [CrossRef]

247. Kim, S.H.; Kang, J.G.; Kim, C.S.; Ihm, S.H.; Choi, M.G.; Yoo, H.J.; Lee, S.J. Novel heat shock protein 90 inhibitor NVP-AUY922 synergizes with the histone deacetylase inhibitor PXD101 in induction of death of anaplastic thyroid carcinoma cells. J. Clin. Endocrinol. Metab. 2015, 100, E253-E261. [CrossRef]

248. White, P.T.; Subramanian, C.; Zhu, Q.; Zhang, H.; Gallagher, R.; Timmermann, B.M.; Blagg, B.S.J.; Cohen, M.S. Novel HSP90 inhibitors effectively target thyroid cancer stem cell function preventing migration and invasion. Surgery 2016, 159, 142-151. [CrossRef]

249. Keller, S.; König, A.K.; Marmé, F.; Runz, S.; Wolterink, S.; Koensgen, D.; Mustea, A.; Sehouli, J.; Altevogt, P. Systemic presence and tumor-growth promoting effect of ovarian carcinoma released exosomes. Cancer Lett. 2009, 278, 73-81. [CrossRef]

250. Cheng, L.; Wu, S.; Zhang, K.; Qing, Y.; Xu, T. A comprehensive overview of exosomes in ovarian cancer: Emerging biomarkers and therapeutic strategies. J. Ovarian Res. 2017, 10,1-9. [CrossRef]

251. Nieuwland, R.; Van Der Post, J.A.M.; Lok Gemma, C.A.R.; Kenter, G.; Sturk, A. Microparticles and exosomes in gynecologic neoplasias. Semin. Thromb. Hemost. 2010, 36, 925-929. [CrossRef]

252. Ciocca, D.R.; Calderwood, S.K. Heat shock proteins in cancer: Diagnostic, prognostic, predictive, and treatment implications. Targeting heat shock proteins in cancer. Heat shock proteins in obesity: Links to cardiovascular disease. Cell Stress Chaperones 2005, 10, 86-103. [CrossRef] [PubMed]

253. Hjerpe, E.; Egyhazi, S.; Carlson, J.; Stolt, M.F.; Schedvins, K.; Johansson, H.; Shoshan, M.; Åvall-Lundqvist, E. HSP60 predicts survival in advanced serous ovarian cancer. Int. J. Gynecol. Cancer 2013, 23, 448-455. [CrossRef] [PubMed]

254. Hoter, A.; Naim, H.Y. Heat shock proteins and ovarian cancer: Important roles and therapeutic opportunities. Cancers 2019, 11, 1389. [CrossRef] [PubMed]

255. Bray, F.; Ferlay, J.; Soerjomataram, I.; Siegel, R.L.; Torre, L.A.; Jemal, A. Global cancer statistics 2018: GLOBOCAN estimates of incidence and mortality worldwide for 36 cancers in 185 countries. CA Cancer J. Clin. 2018, 68, 394-424. [CrossRef] [PubMed]

256. Ghoncheh, M.; Pournamdar, Z.; Salehiniya, H. Incidence and mortality and epidemiology of breast cancer in the world. Asian Pacific J. Cancer Prev. 2016, 17, 43-46. [CrossRef]

257. Johnson, R.H.; Anders, C.K.; Litton, J.K.; Ruddy, K.J.; Bleyer, A. Breast cancer in adolescents and young adults. Pediatr. Blood Cancer 2018, 65. [CrossRef]

258. Murphy, B.L.; Day, C.N.; Hoskin, T.L.; Habermann, E.B.; Boughey, J.C. Adolescents and Young Adults with Breast Cancer have More Aggressive Disease and Treatment Than Patients in Their Forties. Ann. Surg. Oncol. 2019, 26, 3920-3930. [CrossRef] 
259. Yano, M.; Naito, Z.; Tanaka, S.; Asano, G. Expression and roles of heat shock proteins in human breast cancer. Jpn. J. Cancer Res. 1996, 87, 908-915. [CrossRef]

260. Conroy, S.E.; Latchman, D.S. Do heat shock proteins have a role in breast cancer? Br. J. Cancer 1996, 74, 717-721. [CrossRef]

261. Banerjee, S.; Lin, C.F.L.; Skinner, K.A.; Schiffhauer, L.M.; Peacock, J.; Hicks, D.G.; Redmond, E.M.; Morrow, D.; Huston, A.; Shayne, M.; et al. Heat shock protein 27 differentiates tolerogenic macrophages that may support human breast cancer progression. Cancer Res. 2011, 71, 318-327. [CrossRef] [PubMed]

262. Rich, A.L.; Khakwani, A.; Free, C.M.; Tata, L.J.; Stanley, R.A.; Peake, R.B.; Hubbard, R.B.; Baldwin, D.R. Non-small cell lung cancer in young adults: Presentation and survival in the English National Lung Cancer Audit. An Int. J. Med. 2015, 108, 891-897. [CrossRef] [PubMed]

263. Subramanian, J.; Morgensztern, D.; Goodgame, B.; Baggstrom, M.Q.; Gao, F.; Piccirillo, J.; Govindan, R. Distinctive characteristics of non-small cell lung cancer (NSCLC) in the young: A Surveillance, Epidemiology, and End Results (SEER) analysis. J. Thorac. Oncol. 2010, 5, 23-28. [CrossRef] [PubMed]

264. Srivastava, A.; Amreddy, N.; Razaq, M.; Towner, R.; Zhao, Y.D.; Ahmed, R.A.; Munshi, A.; Ramesh, R. Exosomes as Theranostics for Lung Cancer. In Advances in Cancer Research; Academic Press Inc.: Cambridge, MA, USA, 2018; Volume 139, pp. 1-33, ISBN 9780128141694.

(C) 2020 by the authors. Licensee MDPI, Basel, Switzerland. This article is an open access article distributed under the terms and conditions of the Creative Commons Attribution (CC BY) license (http://creativecommons.org/licenses/by/4.0/). 